\title{
WestVirginiaUniversity
}

THE RESEARCH REPOSITORY @ WVU

Graduate Theses, Dissertations, and Problem Reports

2008

\section{Ecology of a central Appalachian white-tailed deer herd at low density}

Shawn M. Crimmins

West Virginia University

Follow this and additional works at: https://researchrepository.wvu.edu/etd

\section{Recommended Citation}

Crimmins, Shawn M., "Ecology of a central Appalachian white-tailed deer herd at low density" (2008). Graduate Theses, Dissertations, and Problem Reports. 2666.

https://researchrepository.wvu.edu/etd/2666

This Thesis is protected by copyright and/or related rights. It has been brought to you by the The Research Repository @WVU with permission from the rights-holder(s). You are free to use this Thesis in any way that is permitted by the copyright and related rights legislation that applies to your use. For other uses you must obtain permission from the rights-holder(s) directly, unless additional rights are indicated by a Creative Commons license in the record and/ or on the work itself. This Thesis has been accepted for inclusion in WVU Graduate Theses, Dissertations, and Problem Reports collection by an authorized administrator of The Research Repository @ WVU. For more information, please contact researchrepository@mail.wvu.edu. 


\title{
ECOLOGY OF A CENTRAL APPALACHIAN WHITE-TAILED DEER HERD AT LOW DENSITY
}

\author{
Shawn M. Crimmins
}

\author{
Thesis submitted to the \\ Davis College of Agriculture, Forestry and Consumer Sciences \\ at West Virginia University \\ in partial fulfillment of the requirements \\ for the degree of \\ Master of Science \\ in \\ Wildlife and Fisheries Resources
}

John W. Edwards, Ph.D., Major Professor

James M. Crum, Ph.D.

Gerald R. Hobbs, Ph.D.

Patrick D. Keyser, Ph.D.

Michael P. Strager, Ph.D.

Division of Forestry and Natural Resources

\author{
Morgantown, West Virginia \\ 2008
}

Keywords: Appalachians, browse, forest management, home-range, Odocoileus virginianus, population density, survival, telemetry, West Virginia, white-tailed deer

Copyright 2008 Shawn M. Crimmins 


\section{ABSTRACT \\ Ecology of a Central Appalachian White-tailed Deer Herd at Low Density}

\section{Shawn M. Crimmins}

White-tailed deer (Odocoileus virginianus) are the most abundant big game species in North America and serve as the dominant herbivore in the majority of the Appalachian region. Despite the abundance of research conducted on this species, relatively little is known of the ecology of white-tailed deer occurring at low densities. Our study population experienced a $75 \%$ decline in population density and a three-fold increase in habitat disturbance via timber harvests between 2002 and 2005. From May 2006 to April 2008 I examined the home-range, survival, and herbivory patterns of a central Appalachian white-tailed deer herd that has recently experienced both a substantial decline in population density and now occurs at extremely low densities (1$3 / \mathrm{km}^{2}$ ). Home-range and core-area size did not differ among age classes in any season. Annual home-range size of yearlings (505 ha) was larger than for adults (313 ha), although core-area size did not differ. Within age classes there were no seasonal differences in home-range or core-area size. Home-range site-fidelity did not differ among age classes for any season or among seasons for any age class. Core-area site fidelity was higher in fall (74\%) than in summer (45\%) or winter (36\%) when pooled across age classes but did not differ among age classes. Survival was lower during the fall (0.89) than during summer (0.99) or winter (0.94). Human-induced mortalities $(n=12)$ constituted $67 \%$ of all observed mortalities during the study; all mortalities were in the adult age class. Woody browse abundance differed among plot types, with clearcut interior (50.16 twigs/plot) plots having more browse than clearcut edge (31.95 twigs/plot) or mature forest (18.93 twigs/plot) plots. Browsing rates of woody plants was higher in clearcut edge plots (5.55\%) than in clearcut interior (3.99\%) or mature forest plots (3.32\%). Observed home-range and core-area sizes were substantially larger than previously reported for the same population prior to declines in density. This supports previous work that suggests home-range size is inversely related to population density and positively correlated with habitat disturbance. Survival rates were similar to previously reported, suggesting that adult survival is robust to changes in population density. Previously reported browsing rates were approximately 5 times the levels reported herein, however such a decrease would be expected with reduced population density and an increase in browse abundance, both of which occurred on the study site. 


\section{ACKNOWLEDGMENTS}

I would like to thank my graduate committee, Dr. John Edwards, Dr. Jim Crum, Dr.

Gerald Hobbs, Dr. Pat Keyser, and Dr. Mike Strager for their support and guidance throughout the duration of this project. I would also like to thank the researchers who initiated research of this deer herd and provided much of the basis for this project: Dr. Karl Miller, Dr. Brad Miller, Dr. Ben Laseter, Dr. Tyler Campbell, and especially Dr. Mark Ford. I am grateful to my fellow graduate students for providing support of all kinds during my time at WVU. I owe a great deal of gratitude to the MeadWestvaco Corporation, Penn-Virginia Resources, the West Virginia Division of Natural Resources, West Virginia University, the Northeast Wildlife Damage Management Cooperative, USDA APHIS-Wildlife Services, the University of Georgia, and the USFS-Northern Research Station for providing funding, equipment, and logistical support for this project and related research.

Many technicians and volunteers provided countless hours in the field, without which this project could not have happened: Carl Beard, Anna Hathaway, Stacey Lowe, Kris Meyers, Steve Ploetz, Jeremy Preston, Dan Quinn, Jim Rising, Chris Runner, Matt Schofield, Jim Sparks, and Michael Uffenbeck. Lastly I would like to thank my wife, Alison for her never ending support and patience throughout this process. 


\section{TABLE OF CONTENTS}

TITLE PAGE

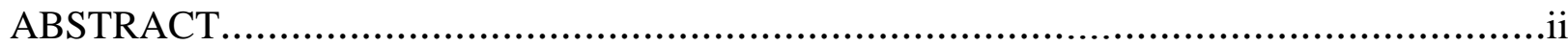

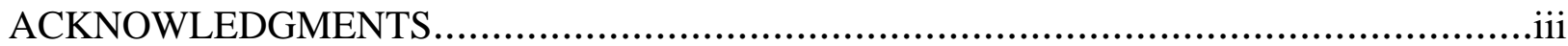

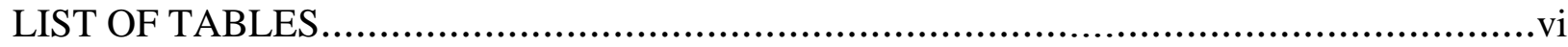

LIST OF FIGURES......................................................................................... CHAPTER 1

INTRODUCTION, RESEARCH JUSTIFICATION AND OBJECTIVES..........................1

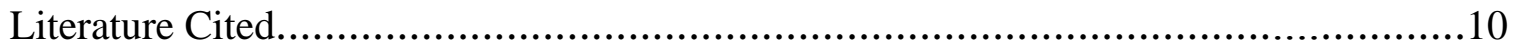

\section{CHAPTER 2}

HOME-RANGE AND SURVIVAL PATTERNS OF FEMALE WHITE-TAILED DEER AT

LOW DENSITY IN THE CENTRAL APPALACHIANS..........................................22

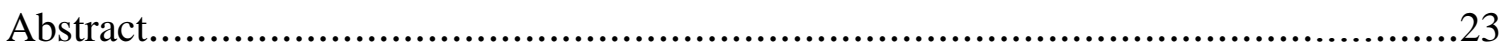

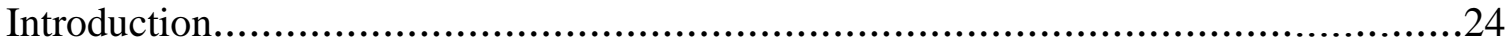

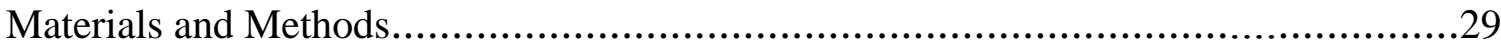

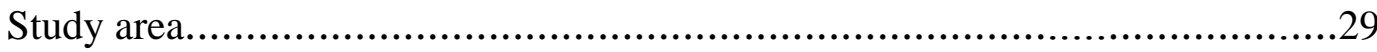

Population estimation............................................................30

Deer capture................................................................... 31

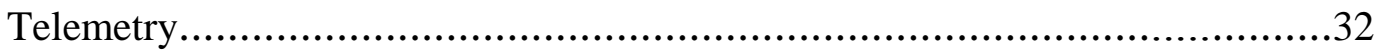

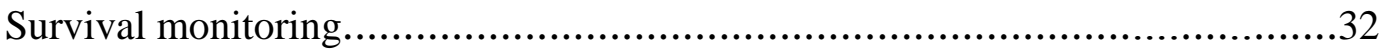

Home-range calculation.............................................................33

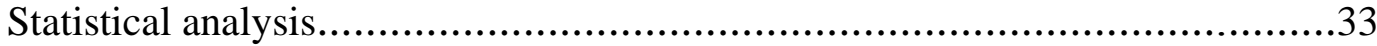

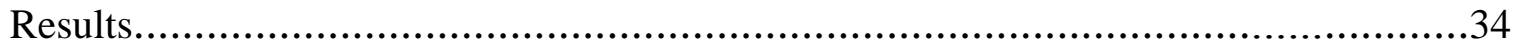

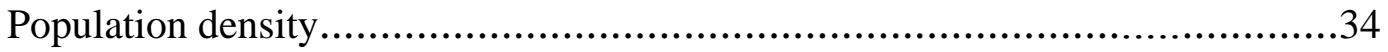

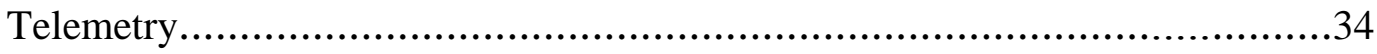

Home-range size............................................................... 34

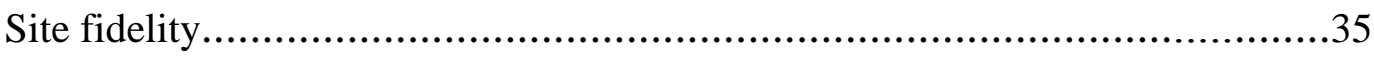




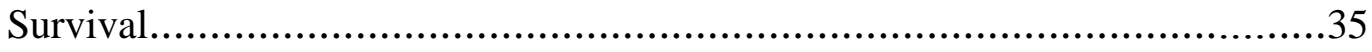

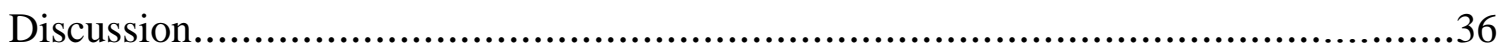

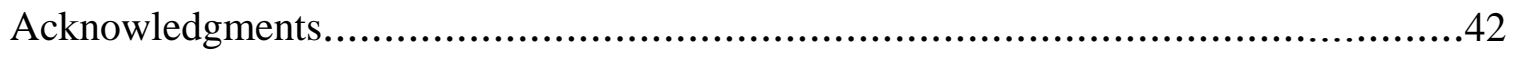

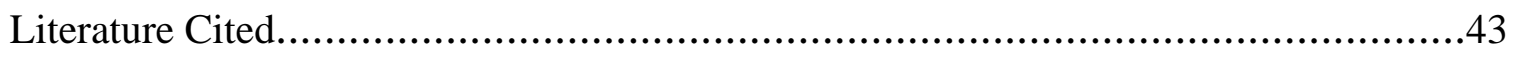

CHAPTER 3

BROWSING PATTERNS OF WHITE-TAILED DEER IN THE CENTRAL APPALACHIANS

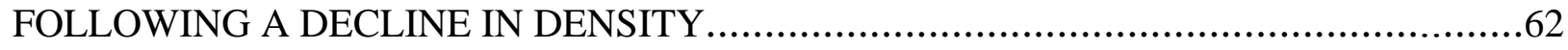

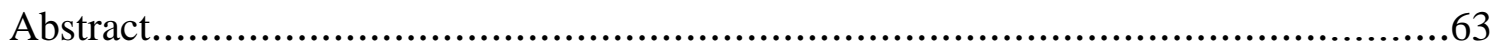

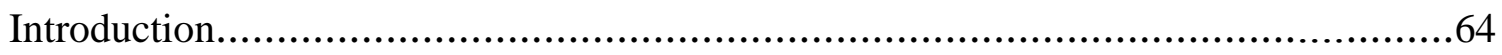

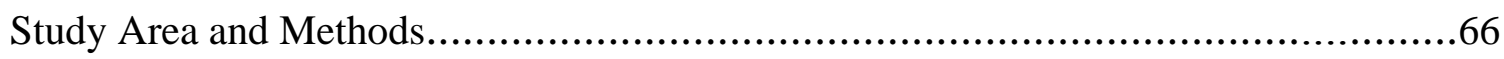

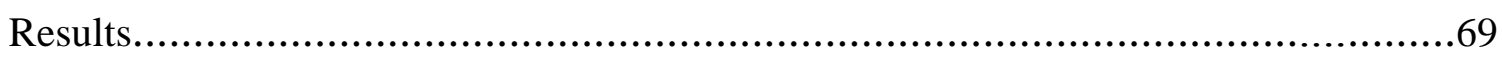

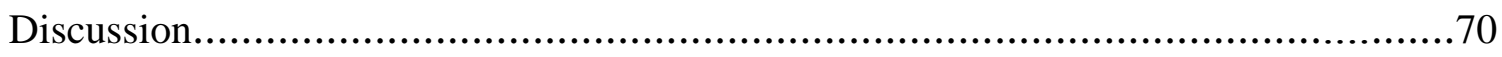

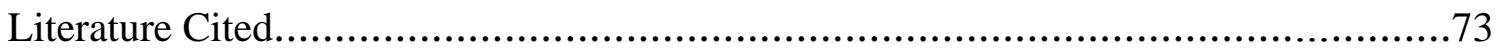




\section{LIST OF TABLES}

CHAPTER 2

2.1 Telemetry locations (SE) collected from May 2006 through April 2008 on the MeadWestvaco Wildlife and Ecosystem Research Forest, West Virginia........55

2.2 Mean home-range and core-area (SE) size in hectares of female white-tailed deer on the MeadWestvaco Wildlife and Ecosystem Research Forest, West Virginia,

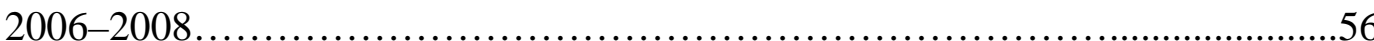

2.3 Mean (SE) percent home-range (HR) and core-area (CA) overlap of female whitetailed deer on the MeadWestvaco Wildlife and Ecosystem Research Forest, West

Virginia, 2006-2008...............................................57

2.4 Adult survival rates and mortality sources for white-tailed deer on the MeadWestvaco Wildlife and Ecosystem Research Forest, West Virginia, 20062008 .58

\section{CHAPTER 3}

3.1 Mean (SE) availability and use of woody browse species in clearcut interior, clearcut edge, and mature forest plots on the MeadWestvaco Wildlife and Ecosystem Research Forest, Randolph County, West Virginia during summer 2007

3.2 Percent of available twigs browsed (PATB), relative abundance (RA), relative use (RU), and white-tailed deer selection for woody browse species on the MeadWestvaco Wildlife and Ecosystem Research Forest, 2007 


\section{LIST OF FIGURES}

\section{CHAPTER 2}

2.1 Kaplan-Meier survival functions for white-tailed deer by season on the MeadWestvaco Wildlife and Ecosystem Research Forest, 2006-2008. Dotted lines represent $95 \%$ confidence limits..........................................60

2.2: $\quad$ Temporal trends in (A) total regeneration area on the MWERF, (B) antlered deer harvest during rifle season, (C) total black bear harvest, and (D) coyotes seen per 1000 hours of hunting from 1995-2007. B, C, and D are collective totals from Pocahontas, Randolph, Tucker, and Webster counties, West Virginia.....

\section{CHAPTER 3}

3.1 Clearcuts sampled on MeadWestvaco Wildlife and Ecosystem Research Forest, Randolph County, West Virginia, 2007

3.2 Proportion of MWERF in early successional (0-5 years post harvest) habitat on the MeadWestvaco Wildlife and Ecosystem Research Forest from 1996-2007...82

3.3 Layout of browse survey plots MeadWestvaco Wildlife and Ecosystem Research

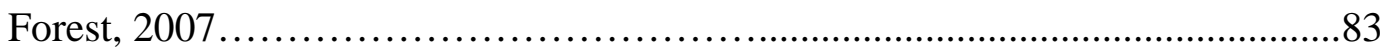

3.4 Woody browse abundance (A) and percent use (B) between study periods on the MeadWestvaco Wildlife and Ecosystem Research Forest. Solid bars represent data from 2001 (Campbell et al. 2006), hatched bars represent data from 2007. Error bars represent \pm one standard error 
3.5 PATB for selected browse species in mature forest (A) and clearcut interior (B) plots between study periods on the MeadWestvaco Wildlife and Ecosystem Research Forest. Solid bars represent data from 2001 (Campbell et al. 2006),

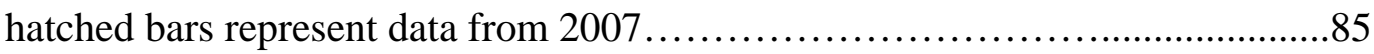




\section{CHAPTER 1}

\section{INTRODUCTION, RESEARCH JUSTIFICATION AND OBJECTIVES}

White-tailed deer (Odocoileus virginianus) are important economically and ecologically in the United States (Conover 1997; Russell et al. 2001). In West Virginia, for example, whitetailed deer hunting generates nearly \$250 million in revenue annually (J. Evans, West Virginia

Division of Natural Resources, personal communication), with national estimates exceeding \$7 billion (Conover 1997). At the turn of the $20^{\text {th }}$ century white-tailed deer populations in the eastern United States were at critically low levels, whereas in recent decades they have risen dramatically in large part due to human induced habitat alterations, historic harvest limitations, and a lack of natural predators (McShea et al. 1997). White-tailed deer have rebounded and are now the most widespread and abundant large herbivore in the eastern United States. Some parts of the eastern United States have seen deer populations increase ten-fold or more in recent decades (Knox 1997). In many parts of the eastern United States, deer are now considered overabundant and are sometimes viewed as a nuisance by the general public due to their potential economic impacts such as crop damage and vehicle collisions (Conover 1997). Annual estimates of damage caused by overabundant deer exceed $\$ 750$ million nationwide (Conover 1997). The resulting shift in public opinion regarding deer abundance has caused many state agencies to dramatically liberalize deer harvest regulations in an attempt to control burgeoning deer populations (McShea et al. 1997). With many deer herds now approaching and in some cases exceeding carrying capacity, wildlife managers must find a way to curtail population growth and in many cases reduce overall population size (Brown et al. 2000). 
The deleterious effects of an overabundant deer herd can manifest themselves in several forms. Deer, primarily through their patterns of herbivory, have been shown to impact forb growth and diversity (Alverson et al. 1988; Anderson 1994; Peek and Stahl 1997; Augustine and Frelich 1998; Rossell et al. 2005), and forest regeneration and diversity (Anderson and Loucks 1979; Frelich and Lorimer 1985; Tilghman 1989; Allison 1990; Healy 1997; Nugent et al. 2001; Bellingham and Allan 2003; Horsley et al. 2003; Russell and Fowler 2004) through the consumption of acorns and seedlings in hardwood forests (McShea and Schwede 1993; Steiner 1996). Effects of deer herbivory on vegetative structure also can negatively affect wildlife. Reductions in songbird productivity (McShea et al. 1995; Allombert et al. 2005a) and insect abundance and diversity (Allombert et al. 2005b) have resulted from intensive deer browsing. In the hardwood dominated forests of the eastern United States, browsing pressure from overabundant deer herds can have profound impacts on forest regeneration and composition (Marquis 1981; Asnani et al. 2006; Holladay et al. 2006; Krueger and Peterson 2006; Rossell et al. 2007). Many highly selected browse species of white-tailed deer also are species of high economic value (Castleberry et al. 1999; Campbell et al. 2006), and intensive browsing pressure on these species can alter forest communities (Rooney and Waller 2003) or almost completely eliminate forest regeneration (Tilghman 1989). Although herbivory patterns of white-tailed deer have been studied on managed forests in the eastern United States (Ford et al. 1993; Castleberry et al. 1999; Campbell et al. 2006), few studies have directly assessed the impacts of deer density on overall browsing pressure (see deCalesta 1994). Additionally, most studies of deer browsing in relation to population density have utilized enclosures and have measured browsing across a small spatial scale such as within a single enclosure (e.g. deCalesta 1994) rather than across an entire forest, highlighting the need for studies of browsing pressure of free-ranging deer 
populations (see Horseley et al. 2003). The potential economic impact of over browsing is the primary motivation for reducing deer densities in forest regeneration areas (Conover 1997). These deleterious effects commonly manifest themselves when deer densities exceed biological carrying capacity (Vila et al. 2003).

Many factors can affect white-tailed deer population density, such as predation (Brinkman et al. 2004), harvest (McCullough 1979), recruitment (Keyser et al. 2005a), and natural mortality sources such as disease (Gaydos et al. 2004) and winter weather (DelGuidice et al. 2002). Regulated harvest can affect deer densities in certain situations, but primarily when the harvest is focused on female animals (McCullough et al. 1991). This effect is a result of recruitment and productivity patterns of deer herds, which exhibit the strongest density dependence relative to the adult female portion of the population rather than population size (McCullough 1984; Teer 1984; Keyser et al. 2005a), although total harvest does affect population regulation due to direct removal of animals (Patterson and Power 2002; Keyser et al. 2005a). Winter weather conditions also are important factors in limiting deer populations, particularly in northern latitudes (Mech et al. 1987). Although many factors can have an effect on white-tailed deer population density, a combination of several factors often contribute to limiting population growth in most systems (Dumont et al. 2000; Patterson et al. 2002).

In forested ecosystems management efforts to reduce deer herbivory in regenerating forest stands are common. Despite the liberalization of harvest quotas in many states, regulated hunting has been unable to control deer numbers, in part due to declines in hunter numbers (Peterson 2004). This has led to the development of many alternative strategies for reducing the impacts of deer including fencing (VerCauteren et al. 2006a), frightening devices (Beringer et al. 2003), man-made corridors (Foster and Humphrey 1995), and alternative harvest strategies 
(Porter et al. 1991). In many situations, fencing areas to reduce deer access can be effective (VerCauteren et al. 2006a), but it is often cost prohibitive (Hyngstrom and Craven 1988). Because of these factors, fencing is often only justifiable for areas with high-value, short-rotation crops such as orchards or vegetable farms rather than large forest regeneration areas (Caslick and Decker 1979). Frightening devices and repellents have been used successfully in some situations, but were found ineffective in many situations (Beringer et al. 2003; VerCauteren et al. 2005, 2006b). Although many alternative techniques to limit the intensity of deer browsing are available, population reduction is the only cost-effective, large-scale method.

One recent strategy for reducing deer impacts, particularly in areas of forest regeneration, is localized management (Porter et al. 1991; Campbell et al. 2004b). This strategy is based on the socio-spatial structure of white-tailed deer with the central hypothesis being that the removal of entire social units can create sustained areas of low density (McNulty et al. 1997). A sequence of studies in the Adirondack Mountains of New York constituted the first experimental test of this hypothesis and suggested that this strategy may be feasible due to high levels of philopatry and adult survival (Porter et al. 1991; Matthews and Porter 1993; Aycrigg and Porter 1997). However, these studies were conducted on deer populations at relatively low densities (6-12 deer $/ \mathrm{km}^{2}$; McNulty et al. 1997) and may not be applicable in areas with higher deer densities (Miller, 2008). The work of McNulty et al. (1997) and Miller (2008) primarily examined how localized management affected animals in or immediately adjacent to removal areas and did not assess how landscape level changes in population density may have affected ecological patterns at the level of the entire deer herd. Despite the efforts made by wildlife managers to reduce white-tailed deer populations to lower densities, relatively little information exists on ecological patterns of low-density deer herds. Because of their historically high 
numbers and potential to cause ecological damage (McCabe and McCabe 1984; Redding 1995; Vandeelen et al. 1996) much of the recent research has occurred in areas of high deer density.

Studies have addressed the effects of white-tailed deer population density on recruitment (Keyser et al. 2005a), physical condition (Garroway and Broders 2005; Keyser et al. 2005b), and home-range patterns (Henderson et al. 2000; Kilpatrick et al. 2001). Recently several studies assessed changes in the space use patterns of white-tailed deer associated with reductions in density. Henderson et al. (2000) found that urban deer increased their home-range size in response to reduced herd density; however, their study did not examine home-range patterns year-round and was based on a relatively small sample size. Additionally, their usage of the minimum convex polygon (MCP) home-range estimator may call into question the validity of their results due to the biases associated with the MCP estimator (Kernohan et al. 2001). Conversely, Kilpatrick et al. (2001) found that deer decreased their home ranges in response to reduced herd density. However, they only examined annual rather than seasonal home-range patterns, and their small study area may have limited deer movements. Although these and other studies of the effects of density on ungulate home ranges (e.g. Kjellander et al. 2004) have focused on shifts in behavior following a sudden and immediate reduction in densities, to date few comparative studies have focused on the effects of a sustained reduction in population density on deer behavior or biology. In a long-term study of key deer (O. v. clavium) in Florida, Lopez et al. (2005) found that deer decreased their home range size as densities increased. However, attributing their findings exclusively to changes in population density is questionable due to large-scale changes in habitat that likely occurred during the duration of the study (30 years) but were not addressed by the authors. 
Despite these and other studies, little research has examined density-dependent processes in multiple parameters, such as home range and survival, simultaneously or in dynamic habitats such as managed forest systems of the eastern United States. Additionally, few long-term studies of white-tailed deer have examined population parameters (see McCullough 1979 for notable exception) or space-use patterns. Most studies examining deer dynamics in relation to population density have focused instead on reproductive (Johns et al. 1978; Rhodes et al. 1985) or recruitment patterns (Keyser et al. 2005a). Effects of changes in density on home-range patterns have been reported for white-tailed deer in coastal plain and deciduous forests of the eastern United States (Kilpatrick et al. 2001; Williams and DeNicola 2002), for key deer in Florida (Lopez et al. 2005), and roe deer (Capreolus capreolus) in Europe (Kjellander et al. 2004). With the exception of Kilpatrick et al. (2001), these studies reported that home-range size increased as population density decreased. This trend of increasing home range size with decreasing population density is contrary to the hypothesis that an increase in available resources resulting from a decrease in population density will allow animals to gather necessary resources over a smaller area, effectively exhibiting an optimal foraging strategy (Fretwell and Lucas 1970; Rosenzweig 1981; Morris 2003). However, optimal foraging may be a reasonable hypothesis for explaining this pattern if animals are increasing their home range in order to gain access only to higher quality forage. This disparity between hypothesized outcomes and observed behavior has led to little consensus regarding the effects of density changes on home range patterns for ungulates despite a general consensus of the effects of density dependence on many other ecological parameters in ungulates (Owen-Smith 2006; Fuller et al. 2007). Previous studies of the effects of density changes on home-range patterns of ungulates have occurred in static 
environments (Henderson et al. 2000), further highlighting the need for research of white-tailed deer in dynamic landscapes.

Effective management of white-tailed deer requires an understanding of their spatial ecology, particularly in dynamic landscapes (Kernohan et al. 2001). The complex interaction between habitat dynamics and wildlife populations, and their relative influences on each other, has received little attention until recently (Larson et al. 2004; Schaefer and Mahoney 2007; Wittmer et al. 2007). The traditional method of assessing how wildlife species interact with their environments when those environments are assumed to be static may not provide wildlife managers with the best information on which to formulate management decisions. Extensive research of the deer herd on the MeadWestvaco Wildlife and Research Forest (MWERF) in central West Virginia has been conducted since 1999 (Langdon 2001; Campbell 2003; Laseter 2004; Miller 2008). To assess the efficacy of localized deer management in a high density population, a series of studies was conducted on the MWERF (Campbell 2003; Laseter 2004). Deer densities on this site were substantially higher (12-20 deer $/ \mathrm{km}^{2}$; Langdon 2001) than those from previous studies of localized management in the Adirondacks (6-12 deer $/ \mathrm{km}^{2}$ McNulty et al. 1997). Following initial studies that examined the social and spatial structure of this deer herd (Campbell et al. 2004b), efforts were conducted to remove entire social groups from the site. Following removal efforts, areas from which deer had been removed were recolonized by deer from surrounding areas, suggesting that localized management may not be effective in high density herds (Miller et al. 2007). However, neither the research conducted in New York nor that conducted in West Virginia examined the effects of localized management beyond the time frame of two to three years after removal, nor did they examine the effects of their manipulations of population density on the entire deer herd. 
Assessment of potential limiting factors often requires estimates of population density. Accurate estimates of population size are critical for proper management (Mayer et al. 2002) and inferences regarding density-dependent processes. Although many techniques exist for estimating white-tailed deer population size, including pellet-group counts (Neff 1968), remote cameras (Jacobson et al. 1997), aerial surveys (DeYoung 1985), and spotlight counts (Roberts et al. 2006), distance sampling is generally considered one of the best methods due to its relative accuracy and limited costs compared to other methods (Langdon 2001; Lopez et al. 2004; Roberts et al. 2006). Distance sampling requires minimal assumptions about the target population (Buckland et al. 2001) and uses widely accepted model fitting criteria in order to generate abundance estimates (Akaike 1973; Buckland et al. 2001).

Current density estimates suggest that the MWERF deer herd has declined by approximately 75\% since 2000 (S. Crimmins, unpublished data) indicating that effects of herd management (e.g. localized management) may have manifested at the population level rather than at the level of individual family units. Research activities (e.g. removal of deer for localized management) may have combined with other factors to precipitate this decline in population since the number of animals removed for research activities $(n=110)$ does not completely account for the reduction in density on the entire site $(n \sim 300)$. High over-winter survival rates of adult deer on the MWERF suggest that recent winter conditions have had little effect on the population (B. Miller, University of Georgia, pers. comm.), while hunter harvest on the MWERF was limited due to restricted access, thus reducing hunting pressure when compared to more accessible land in the region. Although fawn survival and recruitment have not been quantified, fecundity rates have increased as density has been reduced even though fawn:doe ratios are still relatively low (S. Crimmins, unpublished data), indicating that fawns are not surviving from 
parturition to recruitment (Keyser et al. 2005a; Bender 2006). Such evidence suggests that other factors, such as coyote (Canis latrans) and black bear (Ursus americanus) predation of neonates (Kunkel and Mech 1994; Ballard et al. 1999, 2001; Whitaker and Lindzey 1999; Vreeland et al. 2004), may be limiting this deer population. However, the population declines seen on the MWERF are not unique, as harvest data suggests that deer populations throughout the region have experienced similar declines (WV DNR, unpublished data). Previous research assessing population density (Langdon 2001), home range (Campbell et al. 2004a; 2004b), survival (Campbell et al. 2005) and herbivory (Campbell et al. 2006) patterns of the white-tailed deer herd on the MWERF provides a unique opportunity not only to assess ecological parameters for a low-density population, but to also compare these parameters to those previously found at higher population densities.

Specific objectives of my study were to:

Objective 1: Quantify seasonal home-range patterns of white-tailed deer at low population density on the MWERF

$\mathrm{H}_{1}$ : White-tailed deer on the MWERF will have larger home ranges at low population density than previously recorded at higher population densities

$\mathrm{H}_{2}$ : White-tailed deer on the MWERF will exhibit lower levels of philopatry at low population density than previously recorded at higher population densities

Objective 2: Quantify survival and cause-specific mortality rates of white-tailed deer at low population density on the MWERF

$\mathrm{H}_{1}$ : Annual and seasonal survival rates of white-tailed deer on the MWERF will be higher at lower population density than previously recorded at higher population densities 
$\mathrm{H}_{2}$ : Natural mortality rates for white-tailed deer on the MWERF will be lower at low population density to those previously recorded at higher population densities

Objective 3: Quantify browsing patterns of white-tailed deer in regenerating clear-cuts at low population density on the MWERF

$\mathrm{H}_{1}$ : Overall browsing rates of plant species generally selected by white-tailed deer will be lower at low population density to those found at higher population densities

$\mathrm{H}_{2}$ : Overall browsing rates of plant species generally not selected by white-tailed deer will be substantially lower at low population density to those found at higher population densities

\section{LITERATURE CITED}

Akaike, H. 1973. Information theory and an extension of the maximum likelihood principle. Pages 267-281 in B.N. Petran and F. Csaaki, editors. International symposium on information theory, $2^{\text {nd }}$ edition. Akadeemiai Kiadi, Budapest, Hungary.

Allison, T.D. 1990. The influence of deer browsing on the reproductive biology of Canada yew I. direct effects on pollen, ovules, and seed production. Oecologia: 83: 523-529

Allombert, S., A.J. Gaston, and J.L. Martin. 2005a. A natural experiment on the impact of overabundant deer on songbird populations. Biological Conservation: 126: 1-13.

Allombert, S., S. Stockton, and J.L. Martin. 2005b. A natural experiment on the impact of overabundant deer on forest invertebrates. Conservation Biology. 19: 1917-1929.

Alverson, W.S., D.M Waller, and S.L. Solheim. 1988. Forests to deer: edge effects in northern Wisconsin. Conservation Biology: 2: 348-358. 
Anderson, R.C. 1994. Height of white-flowered trillium (Trillium grandiflorum) as an index of deer browsing intensity. Ecological Applications: 4: 104-109.

Anderson R.C., and O. Loucks. 1979. White-tailed deer (Odocoileus virginianus) influence upon structure and composition of Tsuga canadensis forests. Journal of Applied Ecology: 16: 855-861.

Asnani, K.M., R.A. Klips, and P.S. Curtis. 2006. Regeneration of woodland vegetation after deer browsing in Sharon Woods Metro Park, Franklin County, Ohio. Ohio Journal of Science 106: 86-92.

Augustine, D.J., and L.E. Frelich. 1998. Effects of white-tailed deer on populations of an understory forb in a fragmented deciduous forest. Conservation Biology: 12: 995-1004.

Aycrigg, J.L., and W.F. Porter. 1997. Sociospatial dynamics of white-tailed deer in the central Adirondack Mountains, New York. Journal of Mammalogy 78: 468-482.

Ballard, W.B., H.A. Whitlaw, S.J. Young, R.A. Jenkins, and G.J. Forbes. 1999. Predation and survival of white-tailed deer fawns in northcentral New Brunswick. Journal of Wildlife Management: 63: 574-579.

Ballard, W.B., D. Lutz, T.W. Keegan, L.H. Carpenter, and J.C. DeVos. 2001. Deer-predator relationships: a review of recent North American studies with emphasis on mule and blacktailed deer. Wildlife Society Bulletin: 29: 99-115.

Bellingham, P.J., and C.N. Allan. 2003. Forest regeneration and the influences of white-tailed deer (Odocoileus virginianus) in cool temperate New Zealand rain forests. Forest Ecology and Management: 175: 71-86.

Bender, L.C. 2006. Use of herd composition and age ratios in ungulate management. Wildlife Society Bulletin 34: 1225-1230. 
Beringer, J., K.C. VerCauteren, and J.J. Millspaugh. 2003. Evaluation of an animal-activated scarecrow and a monofilament fence for reducing deer use of soybean fields. Wildlife Society Bulletin 31: 492-498.

Brinkman, T.J., J.A. Jenks, C.S. DePerno, B.S. Haroldson, and R.G. Osborn. 2004. Survival of white-tailed deer in an intensively farmed region of Minnesota. Wildlife Society Bulletin 32: 726-731.

Brown, T.L., D.J. Decker, S.J. Riley, J.W. Erick, T.B. Lauber, P.D. Curtis, G.F. Mattfield. 2000. The future of hunting as a mechanism to control white-tailed deer populations. Wildlife Society Bulletin 28:797-807.

Buckland, S.T., D.R. Anderson, K.P. Burnham, J.L. Laacke, D.L. Borchers, and L. Thomas. 2001. Introduction to distance sampling: estimating abundance of biological populations. Oxford University Press, Oxford, UK.

Campbell, T.A. 2003. Movement ecology of white-tailed deer in the central Appalachians. $\mathrm{PhD}$ dissertation, University of Georgia, Athens, GA. 179 pages.

Campbell, T.A., B.R. Laseter, W.M. Ford, and K.V. Miller. 2004a. Topographic home ranges of white-tailed deer in the central Appalachians. Southeastern Naturalist 3: 645-652.

Campbell, T.A., B.R. Laseter, W.M. Ford, and K.V. Miller. 2004b. Feasibility of localized management to control white-tailed deer in forest regeneration areas. Wildlife Society Bulletin: 32: 1124-1131.

Campbell. T.A., B.R. Laseter, W.M. Ford, K.V. Miller. 2005. Population characteristics of a central Appalachian white-tailed deer herd. Wildlife Society Bulletin 33(1): 212-221. 
Campbell, T.A., B.R. Laseter, W.M. Ford, R.H. Odom, and K.V. Miller. 2006. Abiotic factors influencing deer browsing in West Virginia. Northern Journal of Applied Forestry. 23: 2026.

Caslick, J.W., and D.J. Decker. 1979. Economic feasibility of a deer-proof fence for apple orchards. Wildlife Society Bulletin 7: 173-175.

Castleberry, S.B., W.M. Ford, K.V. Miller, and W.P. Smith. 1999. White-tailed deer browse preferences in a southern bottomland hardwood forest. Southern Journal of Applied Forestry 23: 78-82.

Conover, M.R. 1997. Monetary and intangible valuation of deer in the United States. Wildlife Society Bulletin 25:298-305.

deCalesta, D.S. 1994. Effect of white-tailed deer on songbirds within managed forests in Pennsylvania. Journal of Wildlife Management 58: 711-718.

DelGuidice, G.D., M.R. Riggs, P. Joly, and P. Wei. 2002. Winter severity, survival, and causespecific mortality of female white-tailed deer in north-central Minnesota. Journal of Wildlife Management 66: 698-717.

DeYoung, C.A. 1985. Accuracy of helicopter surveys of deer in south Texas. Wildlife Society Bulletin 13: 146-149.

Dumont, A., M. Crete, J.P. Ouellet, J. Huot, and J. Lamoureux. 2000. Population dynamics of northern white-tailed deer during mild winters: evidence of regulation by food competition. Canadian Journal of Zoology 78: 764-776.

Ford, W.M., A.S. Johnson, P.E. Hale, and J.M. Wentworth. 1993. Availability and use of spring and summer woody browse by deer in clearcut and uncut forests of the southern Appalachians. Southern Journal of Applied Forestry 17: 116-119. 
Foster, M.L., and S.R. Humphrey. 1995. Use of highway underpasses by Florida panthers and other wildlife. Wildlife Society Bulletin 23: 95-100.

Frelich L.E., and C.G. Lorimer. 1985. Current and predicted long-term effects of deer browsing in hemlock forests in Michigan, USA. Biological Conservation 34: 99-120.

Fretwell, S.D., and H.L. Lucas Jr. 1970. On territorial behavior and other factors influencing habitat distribution in birds. I. Theoretical development. Acta Biotheoretica 19: 16-36.

Fuller, J.A., R.A. Garrott, and P.J. White. 2007. Emigration and density dependence in Yellowstone bison. Journal of Wildlife Management 71: 1924-1933.

Garroway, C.J., and H.G. Broders. 2005. The quantitative effects of population density and winter weather on the body condition of white-tailed deer (Odocoileus virginianus) in Nova Scotia, Canada. Canadian Journal of Zoology 83: 1246-1256.

Gaydos, J.K., J.M. Crum, W.R. Davidson, S.R. Cross, S.F. Owen, and D.E. Stallknecht. 2004. Epizootiology of an epizootic hemorrhagic disease outbreak in West Virginia. Journal of Wildlife Diseases 40: 383-393.

Healy, W.M. 1997. Influence of deer on the structure and composition of oak forests in central Massachusetts. Pages 249-266 in W.J. McShea, H.B. Underwood, and J.H. Rappole, editors. The science of overabundance: deer ecology and management. Smithsonian Institution Press, Washington, D.C., USA.

Henderson, D.W., R.J. Warren, J.A. Cromwell, and R.J. Hamilton. 2000. Responses of urban deer to a 50\% reduction in local density. Wildlife Society Bulletin. 28: 902-910.

Holladay, C.A., C. Kwit, and B. Collins. 2006. Woody regeneration in and around aging southern bottomland hardwood forest gaps: effects of herbivory and gap size. Forest Ecology and Management 223: 218-225. 
Horsley, S.B., S.L. Stout, and D.S. DeCalesta. 2003. White-tailed deer impacts on the vegetation dynamics of a northern hardwood forest. Ecological Applications. 13: 98-118. Hyngstrom, S.E., and S.R. Craven. 1988. Electric fences and commercial repellents for reducing deer damage in cornfields. Wildlife Society Bulletin 16: 291-296.

Jacobson, H.A., J.C. Kroll, R.W. Browning, B.H. Koerth, and M.H. Conway. 1997. Infraredtriggered cameras for censusing white-tailed deer. Wildlife Society Bulletin 25: 547-556.

Kernohan, B.J., R.A. Gitzen, and J.J. Millspaugh. 2001. Analysis of animal space use and movements. Pages 125-166 in J.J. Millspaugh and J.M. Marzluff, editors. Radio tracking and animal populations. Academic Press, San Diego, CA, USA.

Keyser, P.D., D.C. Guynn, Jr., and H.S. Hill, Jr. 2005a. Density-dependent recruitment patterns in white-tailed deer. Wildlife Society Bulletin 33: 222-232.

Keyser, P.D., D.C. Guynn, Jr., and H.S. Hill, Jr. 2005b. Population density-physical condition relationships in white-tailed deer. Journal of Wildlife Management 69: 356-365.

Kilpatrick, H.J., S.M. Spohr, K.K. Lima. 2001. Effects of population reduction on home ranges of female white-tailed deer at high densities. Canadian Journal of Zoology: 79: 949-954.

Kjellander, P., A.J.M. Hewison, O. Liberg, J.M. Angibault, E. Bideau, and B. Cargnelutti. 2004. Experimental evidence for density-dependence of home-range size in roe deer (Capreolus capreolus L.): a comparison of two long-term studies. Oecologia 139: 478-485.

Knox, W.M. 1997. Historical changes in the abundance and distribution of deer in Virginia. Pages 27-36 in W.J. McShea, H.B. Underwood, and J.H. Rappole, editors. The Science of Overabundance: Deer Ecology and Population Management. Smithsonian Institution Press, Washington DC, USA. 
Krueger, L.M., and C.J. Peterson. 2006. Effects of white-tailed deer on Tsuga canadensis regeneration: evidence of microsites as refugia from browsing. American Midland Naturalist 156: 353-362.

Kunkel, K.E., and L.D. Mech. 1994. Wolf and bear predation on white-tailed deer fawns in northeastern Minnesota. Canadian Journal of Zoology 72:1557-1565.

Langdon, C.A. 2001. A Comparison of white-tailed deer population estimation methods in West Virginia. M.S. Thesis, West Virginia University, Morgantown, WV. 119 pages.

Larson, M.A., F.R. Thompson, J.J. Millspaugh, W.D. Dijak, and S.R. Shifley. 2004. Linking population viability, habitat suitability, and landscape simulation models for conservation planning. Ecological Modelling. 180: 103-118.

Laseter, B.R. 2004. Sociospatial characteristics and genetic structure of white-tailed deer in the central Appalachians of West Virginia. PhD dissertation. University of Georgia, Athens, GA, USA. 115 pages.

Lopez, R.L., N.J. Silvy, B.L. Pierce, P.A. Frank, M.T. Wilson, and K.M. Burke. 2004. Population density of the endangered Florida key deer. Journal of Wildlife Management 68: 570-575.

Lopez, R.L., P.M. Harveson, M.N. Peterson, N.J. Silvy, and P.A. Frank. 2005. Changes in ranges of Florida Key deer-does population density matter? Wildlife Society Bulletin 33: 343-348.

Marquis, D.A. 1981. Effect of deer browsing on timber production in Allegheny hardwood forests of northwestern Pennsylvania. USDA Forest Service, Research Paper NE-475. Matthews, N.E., and W.F. Porter. 1993. Effect of social structure on genetic structure of freeranging white-tailed deer in the Adirondack Mountains. Journal of Mammalogy 74: 33-43. 
Mayer, M.S., T.K. Fuller, R.D. Deblinger, and J.E. McDonald. 2002. Can low-precision population and survival estimates of deer be accurate? Wildlife Society Bulletin 30: 440448.

McCabe, R.E., and T.R. McCabe. 1984. Of slings and arrows: an historical retrospection. Pages 19-72 in L.K. Halls, editor. White-tailed deer ecology and management. Stackpole Books, Harrisburg, PA, USA.

McCullough, D.R. 1979. The George Reserve deer herd: population ecology of a K-selected species. University of Michigan Press, Ann Arbor, Michigan, USA.

McCullough, D.R. 1984. Lessons from the George Reserve. Pages 211-242 in L.K. Halls, editor. White-tailed deer: ecology and management. Stackpole Books, Harrisburg, PA, USA.

McCullough, D.R., D.S. Pine, D.L.Whitmore, T.M. Mansfield, and R.H. Decker. 1991. Linked sex harvest strategy for big game management with a test case on black-tailed deer. Wildlife Monographs: 112.

McNulty, S.A., W.F. Porter, N.E. Matthews, and J.A. Hill. 1997. Localized management for reducing white-tailed deer populations. Wildlife Society Bulletin: 25: 265-271.

McShea, W.J., and G. Schwede. 1993. Variable acorn crops: responses of white-tailed deer and other mast consumers. Journal of Mammalogy: 74: 999-1006.

McShea, W.J., M.V. McDonald, G.E. Morton, R. Meier, and J.H. Rappole. 1995. Long-term monitoring of Kentucky Warbler habitat selection. Auk 112: 375-381.

McShea, W.J., J.B. Underwood, and J.H. Rappole. 1997. The science of overabundance. Pages 1-7 in W.J. McShea, J.B. Underwood, and J.H. Rappole, editors. The science of overabundance: deer ecology and management. Smithsonian Institution Press, Washington, D.C., USA. 
Mech, L.D., R.E McRoberts, R.O. Peterson, and R.E. Page. 1987. Relationship of deer and moose populations to previous winters’ snow. Journal of Animal Ecology: 56: 615-627.

Miller, B.F., R.W. DeYoung, T.A. Campbell, B.R. Laseter, W.M. Ford, and K.V. Miller. 2007. Social structuring of a central Appalachian deer herd and a test of localized management. Abstracts of the Annual Southeast Deer Study Group 30: 16.

Miller, B.F. 2008. Social structuring of a central Appalachian deer herd and a test of localized management. Ph.D. dissertation, University of Georgia, Athens, GA. 137 p.

Morris, D.W. 2003. Toward an ecological synthesis: a case for habitat selection. Oecologia 136: $1-13$.

Neff, D.J. 1968. The pellet-group count technique for big game trend, census, and distribution: a review. Journal of Wildlife Management 32: 597-614.

Nugent, G., W. Fraser, and P. Sweetapple. 2001. Top down or bottom up? Comparing the impacts of introduced arboreal possums and 'terrestrial' ruminants on native forests in New Zealand. Biological Conservation: 99: 65-80.

Owen-Smith, N. 2006. Demographic determination of the shape of density dependence for three African ungulate populations. Ecological Monographs 76: 93-109.

Patterson, B.R., and V.A. Power. 2002. Contributions of forage competition, harvest and climate fluctuation to changes in population growth of northern white-tailed deer. Oecologia: 130: $62-71$.

Patterson, B.R., B.A. Macdonald, B.A. Lock, D.G. Anderson, and L.K. Benjamin. 2002. Proximate factors limiting population growth of white-tailed deer in Nova Scotia. Journal of Wildlife Management 66: 511-521. 
Peek, L.J., and J.F. Stahl. 1997. Deer management techniques employed by the Columbus and Franklin County Park District, Ohio. Wildlife Society Bulletin: 25: 440-442.

Peterson, M.N. 2004. An approach for demonstrating the social legitimacy of hunting. Wildlife Society Bulletin 32: 310-321.

Porter, W.F., N.E. Matthews, H.B. Underwood, R.W. Sage, and D.F. Behrend. 1991. Social organization of deer: implications for localized management. Environmental Management 15: 809-814.

Redding, J. 1995. History of deer population trends and forest cutting in the Allegheny National Forest. Pages 214-224 in Proceedings of the $10^{\text {th }}$ Central Hardwood Conference. Bromall, PA, USA.

Roberts, C.W., B.L. Pierce, A.W. Braden, R.R. Lopez, N.J. Silvy, P.A. Frank, and D. Ransom. 2006. Comparison of camera and road survey estimates for white-tailed deer. Journal of Wildlife Management 70: 263-267.

Rooney, T.P., and D.M. Waller. 2003. Direct and indirect effects of white-tailed deer in forest ecosystems. Forest Ecology and Management 181: 165-176.

Rosenzweig, M.L. 1981. A theory of habitat selection. Ecology 62: 327-335.

Rossell, C.R. Jr., B. Gorsira, and S. Patch. 2005. Effects of white-tailed deer on vegetation structure and woody seedling composition in three forest types on the Piedmont Plateau. Forest Ecology and Management: 210: 415-424.

Rossell, C.R. Jr., S. Patch, and S. Salmons. 2007. Effects of deer browsing on native and nonnative vegetation in a mixed oak-beech forest on the Atlantic coastal plain. Northeastern Naturalist 14: 61-72. 
Russell, F.L., D.B. Zippin, and N.L. Fowler. 2001. Effects of white-tailed deer (Odocoileus virginianus) on plants, plant populations and communities: a review. American Midland Naturalist: 146: 1-26.

Russell, F.L., and N.L. Fowler. 2004. Effects of white-tailed deer on the population dynamics of acorns, seedling and small saplings of Quercus bucleyi. Plant Ecology: 173: 59-72.

Schaefer, J.A., and S.P. Mahoney. 2007. Effects of progressive clearcut logging on Newfoundland caribou. Journal of Wildlife Management 71: 1753-1757.

Steiner, K.C. 1996. Autumn predation of northern red oak seed crops. Pages 489-494 in K.W. Gottschalk, and S.L. Fosbroke, editors. $10^{\text {th }}$ Central Hardwood Forest Conference. United States Department of Agriculture, Forest Service, General Technical Report NE-197: 1577.

Teer, J.G. 1984. Lessons from the Llano Basin, Texas. Pages: 261-290 in L.K. Halls, editor. White-tailed deer: ecology and management. Stackpole Books, Harrisburg, PA, USA. Tilghman, N.G. 1989. Impacts of white-tailed deer on forest regeneration in northwestern Pennsylvania. Journal of Wildlife Management. 53: 524-532.

Vandeelen, T.R., K.S. Pregtizer, and J.B. Haufler. 1996. A comparison of presettlement and present day forests in two northern Michigan deer yards. American Midland Naturalist: 135: 181-195.

VerCauteren, K.C., J.A. Shivik, M.J. Lavelle. 2005. Efficacy of an animal-activated frightening device on urban elk and mule deer. Wildlife Society Bulletin 33: 1282-1287.

VerCauteren, K.C., M.J. Lavelle, and S.E. Hyngstrom. 2006a. Fences and deer-damage management: a review of designs and efficacy. Wildlife Society Bulletin 34: 191-200. 
VerCauteren, K.C., J.M. Gilsdorf, S.E. Hyngstrom, P.B. Fioranelli, J.A. Wilson, and S. Barras. 2006b. Green and blue lasers are ineffective for dispersing deer at night. Wildlife Society Bulletin 34: 371-374.

Vila, B., F. Torre, F. Guibal, and J.L. Martin. 2003. Growth changes of young Picea sitchensis in response to deer browsing. Forest Ecology and Management 180: 413-424.

Vreeland, J.K, D.R. Diefanbach, and B.D. Wallingford. 2004. Survival rates, mortality causes, and habitats of Pennsylvania white-tailed deer fawns. Wildlife Society Bulletin: 32: 542553.

Whitaker, D.G., and F.G. Lindzey. 1999. Effect of coyote predation on early fawn survival in sympatric deer species. Wildlife Society Bulletin 27: 256-262.

Williams, S.C., and A.J. DeNicola. 2002. Home range increase of lactating female white-tailed deer following herd reduction. Northeast Wildlife 57: 29-38.

Wittmer, H.U., B.N. McLellan, R. Serrouya, and C.D. Apps. 2007. Changes in landscape composition influence the decline of a threatened woodland caribou population. Journal of Animal Ecology 76: 568-579. 


\section{CHAPTER 2}

\section{HOME-RANGE AND SURVIVAL PATTERNS OF FEMALE WHITE-TAILED DEER AT LOW DENSITY IN THE CENTRAL APPALACHIANS ${ }^{1}$}

${ }^{1}$ Crimmins, S.M., J.W. Edwards, P.D. Keyser, J.M. Crum, and W.M. Ford. Formatted for the Journal of Mammalogy 
RH: Crimmins et al.-Deer home range patterns

\title{
HOME-RANGE AND SURVIVAL PATTERNS OF FEMALE WHITE-TAILED DEER AT LOW DENSITY IN THE CENTRAL APPALACHIANS
}

\author{
Shawn M. Crimmins, John W. Edwards, Patrick D. Keyser, James M. Crum, W. Mark \\ FORD,
}

Division of Forestry and Natural Resources, West Virginia University, PO Box 6125, Morgantown, WV 25606, USA (SMC, JWE)

Department of Forestry, Wildlife, and Fisheries, University of Tennessee, Knoxville, TN 37996, USA (PDK)

Wildlife Resources, West Virginia Division of Natural Resources, Elkins, WV 26241 USA (JMC) USDA Forest Service, Northern Research Station, PO Box 404, Parsons, WV 26287, USA (WMF)

\section{ABSTRACT}

Relatively little information exists on space-use or survival patterns of white-tailed deer herds occurring at low density or following a decline in density. With many management strategies designed to reduce white-tailed deer populations, understanding how changes in population density may affect such parameters is an important factor to consider. We used radio-telemetry to examine home-range patterns of 33 female deer and survival of 53 female deer in a low density $\left(<4\right.$ deer $\left./ \mathrm{km}^{2}\right)$ population in central West Virginia from 2006-2008. Home-range and core-area sizes did not differ between age classes in any season $(P>0.05)$. Yearling home-range ( $P=0.72)$ and core-area $(P=0.76)$ sizes were similar among seasons. Adult home-range $(P=$ $0.70)$ and core-area $(P=0.38)$ sizes also were similar among seasons. Yearling and adult site fidelity was high for home ranges ( 70\%) and core areas ( 50\%). Fall core-area site fidelity (74\%) was higher than summer (45\%) or winter (36\%). No seasonal differences in home-range site fidelity were found. Human-induced mortality constituted $67 \%$ of observed mortalities ( $n=$ 18 total), all of which resulted from hunter harvest. Our study population exhibited high survival rates, with survival higher in summer (0.990) than in winter (0.943) or fall (0.889). Home-range 
and core-area sizes were substantially larger than previously reported for this population in 1999-2002, when densities were $12-20 / \mathrm{km}^{2}$. Survival rates were similar to those found in 19992002. Our results suggest that reductions in density and increases in habitat patchiness are related to a substantial increase in home-range size. Although we cannot infer a causal relation with these factors, our results do lend support to previous work suggesting that white-tailed deer home-range size displays an inverse relation with population density and a positive relation with habitat patchiness. Our results also support previous work suggesting that adult survival rates are robust to changes in population density and unlikely to exhibit density-dependence.

Key words: Appalachians, home range, Odocoileus virginianus, population density, survival, telemetry, white-tailed deer

\section{INTRODUCTION}

Human-induced habitat alterations, along with reduced hunting pressure and a lack of natural predators, have caused widespread growth of deer populations (McShea et al. 1997). Some parts of the eastern United States have experienced deer populations increase ten-fold or more in recent decades (Knox 1997). In many areas deer are now considered overabundant and are having deleterious ecological effects (Cote et al. 2004). Intensive browsing by deer has been shown to reduce growth rates, ground cover, and species diversity of understory forbs (Alverson et al. 1988; Anderson 1994; Augustine and Frelich 1998; Rossell et al. 2005). Likewise, forest regeneration and diversity also are negatively affected from deer browsing, with areas of high deer density exhibiting limited forest regeneration (Anderson and Loucks 1979; Frelich and Lorimer 1985; Tilghman 1989; Allison 1990; Healy 1997; Nugent et al. 2001; Bellingham and Allan 2003; Horsley et al. 2003; Russell and Fowler 2004). Effects of deer herbivory on vegetative communities also can negatively affect wildlife species. Ground-nesting songbird 
abundance can be reduced in areas with high deer populations due to decreased density and abundance of understory vegetation (McShea and Rappole 2000). McShea et al. (1995) observed that Kentucky warblers (Oporornis fomosus) shifted habitat selection and showed a decrease in breeding territory establishment in areas with high rates of deer herbivory. In British Columbia, areas protected from Sitka black-tailed deer (O. hemionus sitkensis) browsing had higher densities of breeding songbirds, insects, and higher insect species diversity than areas with a history of deer browsing (Allombert et al. 2005a, 2005b). In addition, overabundant deer herds tend to be characterized by animals in poorer physical condition (Keyser et al. 2005a) with higher rates of parasite prevalence than herds at lower density (Eve and Kellogg 1977). This can also lead to a feedback mechanism whereby hunter interest decreases as a result of only being able to harvest animals in poor condition, thus desired harvest objectives to control population size may not be met (Brown et al. 2000), although this rarely occurs. Such deleterious effects commonly manifest themselves when deer densities exceed ecological carrying capacity (Vila et al. 2003). With many deer herds now beyond both cultural and ecological carrying capacity (deCalesta and Stout 1997), wildlife managers must find ways to curtail population growth and in many cases reduce overall population size (Brown et al. 1997). Despite efforts to reduce deer densities, relatively little is known of the ecology of white-tailed deer occurring at low density or following management actions to reduce density.

A variety of techniques have been used in an attempt to reduce deer densities with varying degrees of success. Controlled public hunts have been successful in large-scale applications in Massachusetts (McDonald et al. 2007) and small-scale suburban settings in Connecticut (e.g. Kilpatrick and Walter 1999). Small-scale removal of family groups has also met with success in heavily forested areas with relatively low initial population densities (McNulty et al. 1997), but 
with less success in higher density populations (Miller 2008). Contraceptive and fertility treatments also have been used to reduce deer reproductive capacity with varying levels of success, primarily in urban or suburban settings where lethal control may not be feasible or acceptable (Locke et al. 2007; Rutberg et al. 2004). Physical repellants such as fences (VerCauteren et al. 2006a; Kochenderfer and Ford 2008) have been used in forested areas in the Midwest and Appalachians, while frightening devices (Beringer et al. 2003; VerCauteren 2005; VerCauteren 2006b) also have been used to deter deer usage of specific areas, primarily in agricultural or timbered regions of the Midwest. Regardless of technique, an understanding of how such actions may affect deer populations is critical to proper management.

The relation between deer density and home-range size is important for predicting potential outcomes of management programs designed to reduce deer density. Two competing hypotheses to explain the relation between white-tailed deer population density and home-range size have been proposed. The first, commonly referred to as the "gas molecule” hypothesis (McNulty et al. 1997), predicts that a reduction in density will lead to an increase in home-range size due to increased rates of female dispersal and decreased territorial interactions, which allows for the expansion of home-ranges into previously unavailable or occupied areas. The second hypothesis predicts that decreased population density will lead to a decrease in home-range size due to the philopatric behavior of deer (Tierson et al. 1985; Kilpatrick et al. 2001). A population exhibiting free distribution in habitat selection (Fretwell and Calver 1969) may be expected to conform to the first hypothesis, assuming that at reduced densities there would be fewer territorial interactions that affected space-use patterns. Additionally, optimal foraging theory suggests that animals in such a population may alter their space-use patterns in order to locate and utilize the best habitats and resources where intraspecific competition had been reduced along with a 
concomitant reduction in the utilization of marginal resources, whether through the increased use of high-quality areas within original home ranges or through the expansion of home ranges to additional areas with high-quality resources (Fretwell and Lucas 1970). However, the highly philopatric nature of white-tailed deer would seem to support the second hypothesis and suggest that social behavior (e.g. site fidelity) and interactions are more critical in structuring homerange patterns (McNulty et al. 1997).

Previous research on population density and home-range patterns has produced conflicting results (Henderson et al. 2000; Kilpatrick et al. 2001; Lopez et al. 2005). On the coastal islands of South Carolina, urban deer increased their seasonal home-range sizes in response to a 50\% reduction in local population density (Henderson et al. 2000). Conversely, Kilpatrick et al. (2001) found that deer in suburban Connecticut decreased their annual home-range sizes immediately after the implementation of a herd reduction program. Lopez et al. (2005) found that home-range sizes of Florida key deer (O. virginianus clavium) decreased as population densities increased. Such disparity could result from the availability and distribution of resources in these suburban settings. Studies of white-tailed deer herds in enclosures (Williams and DeNicola 2002) and free-ranging roe deer (Capreolus capreolus) in Europe (Kjellander et al. 2004) also have found an inverse relation between population density and home-range size. In a highly forested landscape in the Adirondacks, McNulty et al. (1997) found that home-range size did not change in response to a localized reduction in density. These contradictory results reflect the complex nature of white-tailed deer home-range patterns and their relations with factors such as density, competition, and habitat structure (Lopez et al. 2005). The work of McNulty et al. (1997) serves as the only contemporary study addressing the relation between population density and home-range patterns of a free ranging white-tailed deer population in a non-urban setting; 
However, their study was based on the removal of a relatively small number of animals $(n=14)$ from a population occurring at moderate to relatively low population density (6-12 deer $/ \mathrm{km}^{2}$ ). Populations occurring at higher density or that have undergone a more substantial change in density may exhibit different patterns from those observed by McNulty et al. (1997). Likewise, high density populations in non-urban landscapes may respond differently to a reduction in density than populations inhabiting urban or suburban landscapes. Despite other studies that have addressed the effect of white-tailed deer population density on recruitment (Keyser et al. 2005b) and physical condition (Garroway and Broders 2005; Keyser et al. 2005a), the effects on home-range patterns remain inconclusive.

Studies of mule deer (Odocoileus hemionus) in Colorado (Bartmann et al. 1992; White and Bartmann 1998) and red deer (Cervus elaphus) in Europe (Clutton-Brock et al. 1987) suggest that population density also may affect fawn survival, although this pattern is not often observed in white-tailed deer (McCullough 1979; Patterson et al. 2002). McCullough (1979, 1990) suggested that adult survival rates are robust to changes in population density in white-tailed deer; however, little empirical evidence exists on such relations. Density-dependence in adult survival has been examined for many other ungulate species. Festa-Bianchet et al. (2003) suggested that apparent density-dependent patterns in adult survival rates of bighorn sheep (Ovis canadensis), mountain goats (Oreamnos americanus), and roe deer (Capreolus capreolus) were actually the result of changes in adult age structure and provided little support for the argument that density-dependent processes were operative. In a study of reindeer (Rangifer tarandus tarandus) population dynamics in Norway, Skogland (1985) found that density-dependent changes in forage abundance affected juvenile survival but had little effect on adult survival. Similarly, Gaillard et al. (1998) found little evidence to support density-dependent changes in 
adult survival rates of ungulates, and suggested that most temporal variation in adult survival rates is a function of rare events such as severe weather or epizootics. This and other research suggests that adult survival rates in white-tailed deer should not exhibit a strong densitydependent trend.

Due to the limited information available on the ecology of low density white-tailed deer herds, our primary objectives were to (1) use radio telemetry to describe seasonal home-range and site-fidelity patterns of female white-tailed deer in a low density population, and (2) identify patterns of adult survival and mortality rates in a low density population. A secondary objective was to compare our results to those previously found for our study population in 1999-2002 when densities were $12-20 / \mathrm{km}^{2}$.

\section{MATERIALS AND METHODS}

Study area.-We conducted our study on the MeadWestvaco Wildlife and Ecosystem Research Forest (MWERF) in central Randolph County, West Virginia. The 3,413 hectare site occurs in the Unglaciated Allegheny Mountain and Plateau physiographic province (Fenneman 1938) and ranges in elevation from 734 to 1,180 meters. Average annual precipitation on the site ranges between 170 and $190 \mathrm{~cm}$ with an average snowfall >300 cm/year (National Oceanic and Atmospheric Administration, 1998-2002). The majority of the site was logged between 1916 and 1928 and is now comprised primarily of second-growth northern hardwood-Allegheny hardwood forests (Keyser and Ford 2005). Forest communities of the MWERF were dominated by American beech (Fagus grandifolia), red maple (Acer rubrum), sugar maple (A. saccharum), yellow poplar (Liriodendron tulipfera), and black cherry (Prunus serotina). Other common species included yellow birch (Betula allegheniensis) American basswood (Tilia americana), black birch (B. lenta), and northern red oak (Ouercus rubra). High elevation areas were 
dominated by red spruce (Picea rubens) and eastern hemlock (Tsuga canadensis) communities. Throughout much of the area, the understory was dominated by greenbrier (Smilax spp.) and mountain laurel (Kalmia latifolia), with dense rosebay rhododendron (Rhododendron maximum), prevalent along riparian areas. Hay-scented fern (Dennstaedtia punctilobula) also was abundant throughout the understory due to excessive herbivory from historically high white-tailed deer densities (Keyser and Ford 2005). Since 2000 more than 500 hectares of forest have been harvested on the MWERF, of which $75 \%$ has been clearcut, with the remaining $25 \%$ in deferment, diameter-limit, and selection harvests. Harvest units vary in size, with even-aged units averaging 15 ha size since the mid-1990's. Clearcuts comprised approximately 5\% of the MWERF at the time of previous research of deer home-range patterns (Campbell et al. 2004a), whereas these regeneration units comprised $>14 \%$ of the MWERF at the time of our study. From 2005 to the present, white-tailed deer densities on the MWERF were substantially lower than found during previous studies of deer home-range patterns conducted from 1999 to 2002 (Langdon 2001; Campbell et al. 2004a).

Population estimation.-We estimated the density of the MWERF deer herd using distance sampling (Buckland et al. 2001). We collected distance data during spotlight surveys conducted in October 2005, January 2006, February and October 2007. We selected a 35-km survey route that provided proportional coverage of the study area and habitat types. Surveys began approximately 30 minutes after sunset and were conducted from a motor vehicle traveling at $12-$ $16 \mathrm{~km} / \mathrm{hr}$. We used a laser range finder to estimate the distance from the survey route to each deer that was sighted. Density estimates were generated using program DISTANCE (Research Unit for Wildlife Population Assessment, University of St. Andrews, Scotland). Our methods 
followed Langdon (2001), whose density estimates were used during previous research of the MWERF deer herd (Campbell et al. 2004a).

Deer capture.-We live captured deer using modified clover traps (Clover 1954) baited with whole kernel corn from January through March in 2005-2007. Upon capture, we restrained, blindfolded, and chemically immobilized deer with an intramuscular injection of xylazine $\mathrm{HCl}$ (Sedazine, Fort Dodge Animal Health, Fort Dodge, IA) at a dosage of $2.2 \mathrm{mg} / \mathrm{kg}$. We aged deer as yearlings ( $\leq 1.5$ years) or adults ( $>1.5$ years) according to tooth eruption and wear patterns (Severinghaus 1949). We fitted deer with VHF radio-collars equipped with an 8-hour mortality switch (Advanced Telemetry Systems, Ishanti, MN). We also placed new radio-collars on captured deer that were wearing collars from previous research (Campbell 2003; Laseter 2004; Miller 2008). We placed a uniquely numbered plastic ear tag on each animal for visual identification (National Band and Tag, Newport, KY). Once deer had been fitted with radio collars and ear tags, we administered a 50\% intramuscular and 50\% subcutaneous injection of yohimbine $\mathrm{HCl}$ (Yobine, Lloyd Laboratories, Shenandoah, IA) at a dosage of $0.3 \mathrm{mg} / \mathrm{kg}$ (Wallingford et al. 1996) as an antagonist. We released all deer at their respective capture sites and monitored them visually until they were ambulatory. All capture and handling methods were in accordance with the guidelines of the American Society of Mamamlogists (Gannon et al. 2007) and the Animal Care and Use Committee of West Virginia University (ACUC\# 05-0706). At the time of our study, a group of approximately 70 animals that were radio-collared as part of previous research activities existed on the MWERF (Campbell 2003; Laseter 2004; Miller 2008). In order to increase our sample size, we also monitored animals from this group that had radiocollars with a sufficient projected battery life to last until the end of our study. All animals monitored during our study were female. 
Telemetry.-We attempted to locate deer once per day 3-4 days per week using biangulation (Mech 1983) or triangulation (White and Garrott 1990) from May 2006 to April 2008. We used 3-element hand-held Yagi antennas and a TRX-1000 receiver (Wildlife Materials, Murphysboro, IL) to locate collared animals. Azimuths were taken from $\geq 2$ georeferenced stations $(n=499)$ located throughout the MWERF with a maximum of 15 minutes between azimuths to reduce the effect of animal movement on location accuracy (Schmutz and White 1990: Katnik et al. 1994; Chapin et al. 1997). We measured our telemetry error by placing 10 radio collars at georeferenced locations throughout the MWERF and recording the estimated azimuths to each collar from at least 10 telemetry stations (White and Garrott 1990) during July 2006. We augmented telemetry locations with visual locations of radio-collared animals identified via numbered ear tags recorded throughout the year.

Survival monitoring.- We located deer $\geq 1$ day each week from 1 August 2006 to 30 April 2008 for a total of 92 observation weeks. We monitored status (dead/alive) from the ground using a TRX-2000S receiver (Wildlife Materials, Murphysboro, IL) and a 3-element Yagi antenna. When a mortality signal was detected, we immediately attempted to locate the individual to determine cause of death. We categorized death as natural or human-induced following Campbell et al. (2005). Collars from animals legally harvested by hunting club members were left at check stations located at entrances to the MWERF, thus we categorized any animal whose collar was found at check stations as human-induced mortality. If we located collars in the field that had been cut off the animal or unfastened, we assumed the cause of death to be illegal harvest and categorized these as human-induced. We categorized all other sources of mortality (e.g., starvation, predation, disease, etc.) as natural. We assumed that no animals lost or "slipped" their collars during the study. 
Home range calculation.-We generated annual and seasonal home-range and core-area estimates using the fixed-kernel method (Worton 1989; Worton 1995; Seaman and Powell 1996) with a least-squares cross-validated bandwidth and reference grid cell size (Gitzen et al. 2006; Kernohan et al. 2001). We used $95 \%$ and 50\% volume contours to define home range and core areas. We calculated seasonal home ranges and core areas for animals with $\geq 30$ locations in a season and annual home ranges and core areas were calculated for animals with $\geq 10$ locations in each season of a year to ensure $\geq 30$ locations for the entire year (Seaman et al. 1999; Leban et al. 2001). We defined seasons as summer (May-September), fall (October-December), and winter (January-April) following Campbell et al. (2004a). We calculated annual home ranges and core areas for May-April. We generated home-range and core-area polygons using the Animal Movements extension in ArcView 3.2 (Hooge and Eichenlaub 2000).

Statistical analysis.-We tested for seasonal and annual differences in home-range size, corearea size, and site fidelity between years using analysis of variance (ANOVA). No differences between years were detected; therefore we pooled data between years to increase our statistical power for subsequent analyses. We tested for seasonal differences in home-range and core-area sizes and site-fidelity using two-way analysis of variance (ANOVA) models that included season as a treatment effect and age as a blocking factor (Zarr 1999). When no differences between age classes were detected, we pooled data between age classes for subsequent seasonal comparisons using a one-way ANOVA model. We used Tukey's honestly significant difference as a multiple range test. We defined seasonal site fidelity as the percentage of an animal's seasonal home range and core area that was overlapped by its home range in the same season of the following year (Lesage et al. 2000). We estimated survival rates using the Kaplan-Meier method (Conroy et al. 1989; Winterstein et al. 2001) with a staggered entry design (Pollock et al. 1989). We 
generated seasonal survival estimates using the Survival package in the R programming language (R Development Core Team 2008). We considered each week as a unique observation period. We defined seasons as summer (1 June-30 September), fall (1 October-31 December), and winter (1 January-31 May) following Campbell et al. (2005). We calculated annual survival rates as the product of seasonal survival rates to account for differences in the lengths of individual seasons.

\section{RESULTS}

Population density.-We were unable to generate population density estimates from the January 2006 and February 2007 surveys due to a limited number of deer sightings in each survey $(n<30)$. The estimated population density from the October 2005 survey, during which we recorded 53 sightings, was $1.2 \mathrm{deer} / \mathrm{km}^{2}(0.4-4.1)$. The estimated population density during the October 2007 surveys, during which we recorded 30 sightings, was 2.6 deer $/ \mathrm{km}^{2}(1.1-5.7)$.

Telemetry.-From May 2006 to April 2008 we collected 5,252 locations from 35 individual animals. Of those, 33 had sufficient locations $(\geq 30)$ to generate at least one seasonal home range and 22 had a sufficient number to generate at least one annual home range. We were able to generate 113 seasonal home ranges using 4,870 locations and 35 annual home ranges using 4,303 locations (Table 2.1). Mean telemetry azimuth error during our field tests was $-1.1^{\circ}\left(\mathrm{SD}=9.6^{\circ}\right.$; $n=120)$.

Home-range size.- Seasonal home-range size did not differ between yearlings and adults in summer $(F=3.44$, d.f. $=41, P=0.07)$, fall $(F=2.43$, d.f. $=32, P=0.13)$, or winter $(F=1.14$, d.f. $=37, P=0.29)$. Seasonal core-area also was similar between age classes in summer $(F=$ $0.03, P=0.86)$, fall $(F=0.30, P=0.59)$, and winter $(F=0.18, P=0.68)$. There were no seasonal differences in yearling home-range $(F=0.34$, d.f. $=12, P=0.72)$ or core area $(F=0.28$, 
$P=0.76)$ sizes. Adult home-range $(F=0.36$, d.f. $=97, P=0.70)$ and core-area $(F=0.96, P=$ $0.38)$ sizes also were similar among seasons. Home-range $(F=0.72$, d.f. $=111, P=0.49)$ and core-area $(F=1.09, P=0.34)$ sizes did not differ among seasons when data were pooled between age classes. Annual home-range size of yearlings was larger than adults $(F=4.38, d$. $f$. $=34, P=0.04)$, annual core-area size did not differ between age classes $(F=1.16, P=0.29)$. Home ranges were generally 7-8 times larger than core areas and were highly variable within seasons (Table 2.2).

Site-fidelity.-Home-range site-fidelity was similar between age classes in summer $(F=0.75$, d.f. $=14, P=0.40)$, fall $(F=1.19$, d.f. $=9, P=0.31)$, winter $(F=0.10$, d.f. $=11, P=0.76)$, and annually $(F=0.71$, d.f. $=12, P=0.42)$. Core-area site-fidelity also was similar between age Classes in summer $(F=0.29, P=0.60)$, fall $(F=1.50, P=0.26)$, winter $(F=0.43, P=0.52)$, and annually $(F=0.75, P=0.40)$. Home-range site-fidelity did not differ among seasons when data were pooled between age classes $(F=0.25$, d.f. $=35, P=0.78)$. Fall core area site-fidelity was higher than summer and winter $(F=5.37, P=0.01)$ when data were pooled between age classes. Home-range site-fidelity was higher than core-area site-fidelity for both age classes in all seasons except for adults in fall (Table 2.3).

Survival.- We monitored 57 female deer (4 yearling, 53 adult) from 1 June 2006 through 30 April 2008 for a total of 4,884 observation weeks. We documented 18 mortality events during this period: 12 human-induced and 6 natural. No mortalities of yearlings were documented, therefore all calculated survival and mortality rates apply only to the adult portion of our sample. Human-induced mortality during the fall hunting season constituted half of all observed mortality events (Table 2.4). We only observed one mortality event in the summer season (natural). Survival was high (>80\%) in all seasons and annually (Table 2.4). Seasonal survival 
was significantly higher in summer than in fall; winter survival rates did not differ from summer or fall survival (Table 2.4).

\section{DISCUSSION}

Population density is a critical factor in structuring ecological patterns of white-tailed deer (Kilpatrick et al. 2001; Keyser et al. 2005a, 2005b; McNulty et al. 1997). Understanding how density affects home-range patterns in deer can be important to aid in developing population management strategies designed to minimize disease transmission and herbivory (Lopez et al. 2005). Despite the abundance of research on white-tailed deer home-range patterns, the effects of density on space use remains poorly understood, particularly when coupled with other factors such as habitat quality and resource distribution. Previous research has suggested that seasonal changes in resource abundance and distribution may affect space-use patterns, including homerange size (Labisky and Fritzen 1998). However, we found no seasonal differences in homerange or core-area size. Differences in annual home-range size between adults and yearlings that we observed were potentially due to our small sample size of yearlings $(n=4)$. Previous research on the MWERF, with larger sample sizes, found no difference in home-range size between yearling and adult deer (Campbell et al. 2004a).

Space-use patterns are often affected by spatial distribution of resources, including levels of patchiness (Ford 1983). Timber harvesting on our study site dramatically increased the interspersion of habitats across the landscape, leading to a nearly three-fold increase in the area of forest regeneration and early successional habitat since the research of Campbell et al. (2004a). An increase in the abundance of regenerating clearcuts from approximately $5 \%$ of the study area in 1999-2002 to nearly 14\% in 2006-2008 increased the amount of browse available to deer during spring and summer, a period of high nutritional requirements for lactating females 
(Wentworth et al. 1990a; Ford et al. 1993). However, this seasonal gain may have come at the expense of a loss of hard mast production due to the harvest of mature trees, which may have reduced the amount of mast available to deer in fall and winter. Thus, it is possible that a zero net gain or a net loss in total forage availability resulted from timber harvests (Wentworth et al. 1990b), although the lack of mast production data from our study site limits our ability to infer that such a process occurred. We found that fall site-fidelity was substantially higher than previously found for the same population when densities were high $\left(12-20 / \mathrm{km}^{2}\right)$. Increases in fall site-fidelity that we observed may have been a result of habitat patchiness and disturbance, whereby deer were more likely to remain in areas capable of producing hard mast due to its decreased availability (Carlock et al. 1993), although empirical data to support this hypothesis are lacking for our study area.

We found that home-range and core-area sizes were approximately $300 \%$ larger than previously reported for this population at high density (Campbell et al. 2004a). Increases in home-range and core-area sizes that we observed were likely attributable to a combination of reduced population density and increased habitat disturbance, although previous findings has suggested that timber harvest had little effect on deer space-use patterns on our study site (Campbell et al. 2004b). However, the research of Campbell et al. (2004b) did not examine space-use patterns more than 3 months after harvest and did not take into account the cumulative effects of previous harvests or the total area of timber harvests. Research in other regions has indicated that population density and habitat patchiness can affect home-range size independently (Ford 1983; Kilpatrick et al. 2001; Lopez et al. 2005), thus it seems reasonable to assume that both factors could act synergistically in this situation. Our study site was subject to increasing levels of disturbance since Campbell et al. (2004a, b) conducted their research (Figure 
2.2A). Although it is possible that home-range sizes on our study site would have increased in the absence of habitat alterations, the confounding effect of habitat disturbance makes it difficult to attribute the increases that we observed exclusively to reductions in population density.

Research of McNulty et al. (1997), Henderson et al. (2000), and Kilpatrick et al. (2001) focused on home-range patterns of deer following rapid and abrupt population reductions. Population reduction on the MWERF was not the direct result of intentional herd management actions per se, but rather the result of a combination of factors that occurred over several years. First, research activities conducted on the MWERF led to the removal of more than 100 individuals from the population between 2002 and 2008 (Miller 2008; J. Crum, unpublished data), directly reducing population size. Secondly, evidence suggests that our study area experienced an increase in predator populations during this time period. Hunter surveys administered by the West Virginia Division of Natural Resources report that coyote (Canis latrans) abundance in the region has increased substantially (Figure 2.2D). Increases in coyote abundance may have led to increased predation rates, particularly of white-tailed deer fawns (Vreeland et al. 2004; Rohm et al. 2007), thus lowering recruitment rates. Additionally, harvest data indicates that black bear (Ursus americanus) populations in the region were also increasing (Figure 2.2C), and the restriction of hunting access to the property reduced bear harvest on our study site and may have led to an increase in bear abundance on the site by effectively creating a sanctuary for winter dens. This potential increase in the abundance of bears on the site may have increased the amount of bear predation on fawns (Ballard and Whitlaw 1999; Vreeland et al. 2004), again lowering recruitment. This issue may have been exacerbated by relatively low reproductive rates exhibited by the MWERF deer herd based on data collected in 2002 and 2005 (Campbell et al. 2005; B. Miller pers. com.), indicating that the fawning season may not have 
represented a prey saturation event, and thus fawns that were born may have been subject to higher predation rates than if a larger number of fawns were available to the predator population. Although little data exists on the survival of fawns on the MWERF, high adult survival rates during our study and previous research lend support to this hypothesis (Crimmins 2008; B. Miller pers. com.). It also could be argued that any reduction in hard mast resulting from timber harvest coupled with harsh winters in 2003 and 2004 may have limited overwinter fawn survival (White and Bartmann 1998). However, insufficient data on mast production from the MWERF exists, and observed increases in fecundity that have not been accompanied by increases in population density do lend support to this hypothesis.

Although we were unable to examine fawn survival patterns, our examination of adult survival rates on our study site does yield insight into the dynamics of this population. Survival rates in adult mule deer in Colorado have been shown to be robust to changes in population density, despite apparent density-dependence in fawn survival rates (Bartmann et al. 1992; White and Bartmann 1998). Furthermore, Bartmann et al. (1992) concluded that mule deer fawn survival rates were still robust to moderate changes in density and that density-dependent responses in survival would only be observed if substantial changes in density occurred. Fowler (1981) suggested that density-dependent processes in large mammals are easier to detect the further the population is from carrying capacity. The deer population on our study area exhibited a substantial decrease ( $\sim 75 \%)$ of a sufficient magnitude to observe density-dependent related mechanisms (McCullough 1990) between the time of previous research (1999-2002) and our study (2006-2008). Additionally, this population was assumed to be near nutritional carrying capacity at the time of previous research (Campbell et al. 2005). Despite this decrease and 
shifting away from biological carrying capacity, the survival rates we observed were similar to those previously reported for this population when densities were high (Campbell et al. 2005).

If density-dependent changes in adult survival were to occur, it would be expected that survival at low population densities would actually increase due to a per-capita increase in available resources (Fretwell and Lucas 1970). Changes in natural mortality rates could result from density-dependence, although previous researchers have emphasized the difficulties in accurately detecting such processes (Festa-Bianchet et al. 2003). Our observed natural mortality rates (6\%) were similar to those found previously at high density (8\%). Although the relative change in natural mortality rate, a decrease of $25 \%$, may seem large , it is effectively negated by the low mortality rates exhibited at high density. In other words, previous mortality rates were so low that there was very little change that could occur even if density-dependence was affecting adult survival in this population. The high survival rates exhibited at both high and low density suggest that resource limitations on our study site never reached a threshold at which they could affect adult survival (Gaillard et al. 2000).

Our results do suggest that survival rates of adult white-tailed deer are highly resistant to changes in population density. The small magnitude of change in survival rates between our study and that of Campbell et al. (2005) may suggest that other factors such as hunting pressure or winter severity may influence survival rates more than population density (Weckerly et al. 2005; Delguidice et al. 2006). In more northern latitudes, winter severity is generally thought to be one of the primary limiting factors for white-tailed deer populations (Garroway and Broders 2005). Although our study site was farther south than where severe winter conditions generally occur, the high elevation made the local climate more similar to that of New England or southeastern Canada than the mid-Atlantic. Still, we observed low natural mortality rates and 
low winter mortality rates, suggesting that winter weather may not have been a substantial contributing factor to adult survival in our population. The high human-induced mortality that we observed was likely due to increased hunting pressure that resulted from a change in ownership and access to our study site rather than a density-dependent process.

We conclude that reduced population density acted synergistically with increased habitat alteration to increase home-range size of white-tailed deer on the MWERF. Although our results are contrary to previous studies (McNulty et al. 1997; Kilpatrick et al. 2001) and seem to support the "gas molecule" hypothesis that decreased intraspecific competition is a driving factor in structuring home-range patterns, the confounding factor of increased per-capita resources limits our ability to attribute our results exclusively to changes in population density. An increase in per-capita resources will occur in a situation where population density is reduced dramatically, even if habitat productivity is held constant. However, our study-site also experienced large scale changes in habitat structure due to extensive timber harvest that were concomitant with reductions in population density. Thus, our results only provide marginal support for the "gas molecule" hypothesis and may suggest that increases in home-range size are not due to increased female dispersal, as proposed by McNulty et al. (1997), but rather due to the spatial structuring of resources. Our results also contradict the findings of McNulty et al. (1997), who suggested that the removal of social units of deer can lead to persisting pockets of low density (i.e. unoccupied habitat patches or territories). The increases in home-range size that we observed suggest that targeted removal of animals might not be effective in creating sustained pockets of low density, as adjacent animals may increase their home ranges in response and thus utilize vacated territories. Our results also suggest that management actions aimed at reducing deer population density can operate under the assumption that adult survival rates, if high prior to 
population reduction, will remain high after population reduction. This is similar to others that have concluded that adult survival rates are extremely robust to changes in population density (McCullough 1979; White and Bartmann 1998). Increases in adult survival rates could counteract population control measures, particularly in areas where maintenance of a low-density population requires intensive population management (McDonald et al. 2007). Our lack of an observed increase in survival rates, particularly when combined with the minimal change in natural mortality rates, suggests that population control measures in areas such as this may be effective at limiting population growth, however this should be interpreted cautiously due to the high survival rates previously exhibited by this population at high density (Campbell et al. 2005). Additionally, the potential for increased fecundity and recruitment would need to be carefully assessed before any population control measures were taken, as these factors are more likely to be density-dependent (Keyser et al. 2005b). Although our study was conducted on a relatively small site, the reduction in population density on the MWERF may not have been a localized occurrence, as harvest data indicates that population densities throughout the region declined substantially during the time period between the research of Campbell et al. (2004a, b, 2005) and our study (Figure 2.2B). As such, our findings are likely applicable to populations across a larger landscape. Our results support previous research suggesting that density-independent factors, such as habitat quality or harvest, may be critical to structuring population dynamics in white-tailed deer.

\section{ACKNOWLEDGMENTS}

Support for this project was provided by the MeadWestvaco Corporation, Penn-Virginia Resources, the West Virginia Division of Natural Resources, and the Division of Forestry and Natural Resources at West Virginia University. We are grateful to B. Miller for his assistance 
with trapping deer. We are also grateful to the many technicians who assisted with data collection.

\section{LITERATURE CITED}

Allombert, S., A.J. Gaston, and J.L. Martin. 2005a. A natural experiment on the impact of overabundant deer on songbird populations. Biological Conservation 126:1-13.

Allombert, S., S. Stockton, and J.L. Martin. 2005b. A natural experiment on the impact of overabundant deer on forest invertebrates. Conservation Biology 19:1917-1929.

Alverson, W.S., D.M. Waller, and S.L. Solheim. 1988. Forests to deer: edge effects in northern Wisconsin. Conservation Biology 2:348-358.

Anderson, R.C. 1994. Height of white-flowered trillium (Trillium grandiflorum) as an index of deer browsing intensity. Ecological Applications 4:104-109.

Augustine, D.J., and L.E. Frelich. 1998. Effects of white-tailed deer on populations of an understory forb in a deciduous forest. Conservation Biology 12:995-1004.

Ballard, W.B., and H.A. Whitlaw. 1999. Predation and survival of white-tailed deer fawns in northcentral New Brunswick. Journal of Wildlife Management 63:574-579.

Bartmann, R.M., G.C. White, and L.H. Carpenter. 1992. Compensatory mortality in a Colorado mule deer population. Wildlife Monographs No. 121.

Bellignham, P.J., and C.N. Allan. 2003. Forest regeneration and the influences of white-tailed deer (Odocoileus virginianus) in cool temperate New Zealand rain forests. Forest Ecology and Management 175:71-86.

Beringer, J., K.C. VerCauteren, and J.J. Millspaugh. 2003. Evaluation of an animal-activated scarecrow and a monofilament fence for reducing deer use of soybean fields. Wildlife Society Bulletin 31: 492-498. 
Brown, T.L., D.J. Decker, S.J. Riley, J.W. Enck, T.B. Lauber, P.D. Curtis, and G.F. Mattfield. 1997. The future of hunting as a mechanism to control white-tailed deer populations. Wildlife Society Bulletin 28:797-807.

Brown, T.L., D.J. Decker, S.J. Riley, J.W. Erick, T.B. Lauber, P.D. Curtis, G.F. Mattfield. 2000. The future of hunting as a mechanism to control white-tailed deer populations. Wildlife Society Bulletin 28:797-807.

Buckland, S.T., D.R. Anderson, K.P. Burnham, J.L. Laacke, D.L. Borchers, and L. Thomas. 2001. Introduction to distance sampling: estimating abundance of biological populations. Oxford University Press, Oxford, UK.

Campbell, T.A. 2003. Movement ecology of white-tailed deer in the central Appalachians of West Virginia. PhD dissertation, University of Georgia, Athens, GA.

Campbell, T.A., B.R. Laseter, W.M. Ford, and K.V. Miller. 2004a. Feasibility of localized management to control white-tailed deer in forest regeneration areas. Wildlife Society Bulletin: 32:1124-1131.

Campbell, T.A., B.R. Laseter, W.M. Ford, and K.V. Miller. 2004b. Movements of female white-tailed deer (Odocoileus virginianus) in relation to timber harvests in the central Appalachians. Forest Ecology and Management 199: 371-378.

Campbell, T.A., B.R. Laseter, W.M. Ford, and K.V. Miller. 2005. Population characteristics of a central Appalachian white-tailed deer herd. Wildlife Society Bulletin 33:212-221.

Carlock, D.M., K.E. Kammermeyer, L.E. McSwain, and E.J. Wentworth. 1993. Deer movements in relation to food supplies in the Southern Appalachians. Proceeding of the Annual Conference of the Southeastern Association of Fish and Wildlife Agencies 47: $16-23$. 
Chapin, T.G., D.J. Harrison, and D.M. Phillips. 1997. Seasonal habitat selection by marten in an untrapped forest preserve. Journal of Wildlife Management 61:707-717.

Clover, M.R. 1954. A portable deer trap and catch-net. California Fish and Game 40:367-373. Clutton-Brock, T.H., M. Major, S.D. Albon, and F.E. Guinness. 1987. Early development and population dynamics in red deer. I. density-dependent effects on juvenile survival. Journal of Animal Ecology 56:53-67.

Conover, M.R. 1997. Monetary and intangible valuation of deer in the United States. Wildlife Society Bulletin 25:298-305.

Conroy, M.J., G.R. Costanzo, and D.B. Stotts. 1989. Winter survival of female American black ducks on the Atlantic coast. Journal of Wildlife Management 53: 99-109.

Cote, S.D., T.P. Rooney, J.P. Tremblay, C. Dussault, and D.M. Waller. 2004. Ecological impacts of deer overabundance. Annual Review of Ecology and Systematics 35:113-147.

Crimmins, S.M. 2008. Ecology of a central Appalachian white-tailed deer herd at low density. M.S. Thesis, West Virginia University, Morgantown, WV.

deCalesta, D.S., and S.L. Stout. 1997. Relative deer density and sustainability: a conceptual framework for integrating deer management and ecosystem management. Wildlife Society Bulletin 25:252-258.

Delguidice, G.D., J. Fieberg, M.R. Riggs, M. Carstensen Powell, and W. Pan. 2006. A longterm age-specific survival analysis of female white-tailed deer. Journal of Wildlife Management 70:1556-1568.

Eve, J.H., and F.E. Kellogg. 1977. Management implications of abomasal parasites in southeastern white-tailed deer. Journal of Wildlife Management 41:169-177. 
Fenneman, N.M. 1938. Physiography of the Eastern United States. McGraw-Hill, New York, 714 pp.

Festa-Bianchet, M., J.M. Gaillard, and S.D. Cote. 2003. Variable age structure and apparent density dependence in survival of adult ungulates. Journal of Animal Ecology 72:640649.

Ford, R.G. 1983. Home range in a patchy environment: optimal foraging predictions. American Zoologist 23: 315-326.

Ford, W.M., A.S. Johnson, P.E. Hale, and J.M. Wentworth. 1993. Availability and use of spring and summer woody browse by deer in clearcut and uncut forests of the southern Appalachians. Southern Journal of Applied Forestry 17:116-119.

Fowler, C.W. 1981. Density dependence as related to life history strategy. Ecology 62: 602610.

Fretwell, S.D., and J.S. Calver. 1969. On territorial behavior and other factors influencing habitat distribution in birds. Acta Biotheoretica 19: 37-44.

Fretwell, S.D., and H.L. Lucas Jr. 1970. On territorial behavior and other factors influencing habitat distribution in birds. I. Theoretical development. Acta Biotheoretica 19:16-36.

Gaillard, J.M., M. Festa-Bianchet, and N.G. Yoccoz. 1998. Population dynamics of large herbivores: variable recruitment with constant adult survival. Trends in Ecology and Evolution 13: 58-63.

Gannon, W.L., R.S. Sikes, and the Animal Care and Use Committee of the American Society of Mammalogists. 2007. Guidelines of the American Society of Mammalogists for the use of wild mammals in research. Journal of Mammalogy 88:809-823. 
Garroway, C.J., and H.G. Broders. 2005. The quantitative effects of population density and winter weather on the body condition of white-tailed deer (Odocoileus virginianus) in Nova Scotia, Canada. Canadian Journal of Zoology 83:1246-1256.

Gese, E.M., O.J. Rongstad, and W.R. Mytton. 1989. Population dynamics of coyotes in southeastern Colorado. Journal of Wildlife Management 53:174-181.

Gitzen, R.A., J.J. Millspaugh, and B.J. Kernohan. 2006. Bandwidth selection for fixed-kernel analysis of animal utilization distributions. Journal of Wildlife Management 70:13341344.

Henderson, D.W., R.J. Warren, J.A. Cromwell, and R.J. Hamilton. 2000. Responses of urban deer to a 50\% reduction in local density. Wildlife Society Bulletin 28:902-910.

Hooge, P.N., and B. Eichenlaub. 2000. Animal movement extension to ArcView ver. 2.0. Alaska Science Center-Biological Science Office, U.S. Geological Survey, Anchorage, AK.

Horsley, S.B., S.L. Stout, and D.S. DeCalesta. 2003. White-tailed deer impacts on the vegetation dynamics of a northern hardwood forest. Ecological Applications 13:98-118.

Katnik, D.D., D.J. Harrison, and T.P. Hodgman. 1994. Spatial relations in a harvested population of marten in Maine. Journal of Wildlife Management 58:600-607.

Kernohan, B.J., R.A. Gitzen, and J.J. Millspaugh. 2001. Analysis of animal space use and movements. Pp. 125-166 in Radio tracking and animal populations (J.J. Millspaugh and J.M. Marzluff, eds.). Academic Press, San Diego, CA.

Keyser, P.D., and W.M. Ford. 2005. Ten years of research on the MeadWestvaco Wildlife and Ecosystem Research Forest: an annotated bibliography. USFS General Technical Report, GTR NE-330. 
Keyser, P.D., D.C. Guynn, Jr., and H.S. Hill, Jr. 2005a. Population density-physical condition relationships in white-tailed deer. Journal of Wildlife Management 69:356-365.

Keyser, P.D., D.C. Guynn, Jr., and H.S. Hill, Jr. 2005b. Density-dependent recruitment patterns in white-tailed deer. Wildlife Society Bulletin 33:222-232.

Kilpatrick, H.J., and W.D. Walter. 1999. A controlled archery deer hunt in a residential community: cost, effectiveness, and deer recovery. Wildlife Society Bulletin 27: 115123.

Kilpatrick, H.J., S.M. Spohr, and K.K. Lima. 2001. Effects of population reduction on home ranges of female white-tailed deer at high densities. Canadian Journal of Zoology 79:949-954.

Kjellander, P., A.J.M. Hewison, O. Liberg, J.M. Angibault, E. Bideau, and B. Cargnelutti. 2004. Experimental evidence for density-dependence of home-range size in roe deer (Capreolus capreolus L.): a comparison of two long-term studies. Oecologia 139:478-485.

Knox, W.M. 1997. Historical changes in the abundance and distribution of deer in Virginia. Pp. 27-36 in The science of overabundance: deer ecology and management (W.J. McShea, H.B. Underwood, and J.H. Rappole, eds.). Smithsonian Institution Press, Washington, D.C.

Kochenderfer, J.N., and W.M. Ford. 2008. Utility of wire cages, tree shelters, and repellents to minimize deer herbivory to oak by white-tailed deer. USFS Research Paper, NRS-5, 8p.

Labisky, R.F., and D.E. Fritzen. 1998. Spatial mobility of breeding female white-tailed deer in a low-density population. Journal of Wildlife Management 62:1329-1334.

Langdon, C.A. 2001. A Comparison of white-tailed deer population estimation methods in West Virginia. M.S. Thesis, West Virginia University, Morgantown, WV. 
Laseter, B.R. 2004. Sociospatial characteristics and genetic structure of white-tailed deer in the central Appalachians of West Virginia. PhD dissertation, University of Georgia, Athens, GA.

Leban, F.A., M.J. Wisdom, E.O. Garton, B.K. Johnson, and J.G. Kie. 2001. Effects of sample size on the performance of resource selection analyses. Pp 291-307 in Radio tracking and animal populations (J.J. Millspaugh and J.M. Marzluff, eds). Academic Press, San Diego, CA.

Lesage, L., M. Crete, J. Hout, A. Dumont, and J. Ouellet. 2000. Seasonal home range size and philopatry in two northern white-tailed deer populations. Canadian Journal of Zoology 78:1930-1940.

Locke, S.L., M.W. Cook, L.A. Harveson, D.S. Davis, R.R. Lopez, N.J. Silvy, and M.A. Fraker. 2007. Effectiveness of Spayvac for reducing white-tailed deer fertility. Journal of Wildlife Diseases 43:726-730.

Lopez, R.L., P.M. Harveson, M.N. Peterson, N.J. Silvy, and P.A. Frank. 2005. Changes in ranges of Florida key deer-does population density matter? Wildlife Society Bulletin 33:343-348.

McCullough, D.R. 1979. The George Reserve deer herd: population ecology of a K-selected species. University of Michigan Press, Ann Arbor, Michigan, USA.

McCullough, D.R. 1990. Detecting density dependence: filtering the baby from the bathwater. Transactions of the North American Wildlife and Natural Resources Conference 55:534543. 
McDonald, J.E., D.E. Clark, and W.A. Woytek. 2007. Reduction and maintenance of a whitetailed deer herd in central Massachusetts. Journal of Wildlife Management 71:15851593.

McNulty, S.A., W.F. Porter, N.E. Matthews, and J.A. Hill. 1997. Localized management for reducing white-tailed deer populations. Wildlife Society Bulletin: 25(2): 265-271.

McShea, W.J., M.V. McDonald, G.E. Morton, R. Meier, and J.H. Rappole. 1995. Long-term monitoring of Kentucky Warbler habitat selection. The Auk 112:375-381.

McShea, W.J., H.B. Underwood, and J.H. Rappole. 1997. The science of overabundance. Pp. 1-7 in The science of overabundance: deer ecology and management (W.J. McShea, H.B. Underwood, and J.H. Rappole, eds.). Smithsonian Institution Press, Washington, D.C.

McShea, W.J., and J.H. Rappole. 2000. Managing the abundance and diversity of breeding bird populations through manipulation of deer populations. Conservation Biology 14:11611170.

Mech, L.D. 1983. Handbook of animal radio-tracking. University of Minnesota Press, Minneapolis, MN.

Miller, K.V. 2008. Considering social behavior in the management of overabundant whitetailed deer populations. Wildlife Society Bulletin 25:279-281.

Miller, B.F. 2008. Social structuring of a central Appalachian deer herd and a test of localized management. PhD dissertation, University of Georgia, Athens, GA.

Morris, D.W. 2003. Toward an ecological synthesis: a case for habitat selection. Oecologia 136:1-13. 
Nugent, G., W. Fraser, and P. Sweetapple. 2001. Top down or bottom up? Comparing the impacts of introduced arboreal possums and 'terrestrial' ruminants on native forests on New Zealand. Biological Conservation 99:65-80.

Patterson, B.R., B.A. Macdonald, B.A. Lock, D.G. Anderson, and L.K. Benjamin. 2002. Proximate factors limiting population growth of white-tailed deer in Nova Scotia. Journal of Wildlife Management 66:511-521.

Peek, L.J., and J.F. Stahl. 1997. Deer management techniques employed by the Columbus and Franklin County Park District, Ohio. Wildlife Society Bulletin 25:440-442.

Pollock, K.H., S.R. Winterstein, C.M. Bunck, and P.D. Curtis. 1989. Survival analysis in telemetry studies: the staggered entry design. Journal of Wildlife Management 53: 7-15.

R Development Core Team. 2008. R: a language and environment for statistical computing. R Foundation for Statistical Computing, Vienna, Austria.

Rohm, J.H., C.K. Nielsen, and A. Woolf. 2007. Survival of white-tailed deer fawns in southern Illinois. Journal of Wildlife Management 71:851-860.

Rosenzweig, M.L. 1981. A theory of habitat selection. Ecology 62:327-335.

Rossell, C.R., B. Gorsira, and S. Patch. 2005. Effects of white-tailed deer on vegetation structure and woody seedling composition in three forest types on the Piedmont Plateau. Forest Ecology and Management 210:415-424.

Russell, F.L., D.B. Zippin, and N.L. Fowler. 2001. Effects of white-tailed deer (Odocoileus virginianus) on plants, plant populations and communities: a review. American Midland Naturalist 146:1-26.

Russell, F.L., and N.L. Fowler. 2004. Effects of white-tailed deer on the population dynamics of acorns, seedling and small saplings of Quercus bucleyi. Plant Ecology 173:59-72. 
Rutberg, A.T., R.E. Naugle, L.A. Thiele, and I.K.M. Liu. 2004. Effects of immuniocontraception on a suburban population of white-tailed deer Odocoileus virginianus. Biological Conservation 116:243-250.

Schmutz, J.A., and G.C. White. 1990. Error in telemetry studies: effects of animal movement on triangulation. Journal of Wildlife Management 54:506-510.

Seaman, D.E., and R.A. Powell. 1996. An evaluation of the accuracy of kernel density estimators for home range analysis. Ecology 77:2075-2085.

Seaman, D.E., J.J. Millspaugh, B.J. Kernohan, G.C. Brundige, K.J. Raedeke, and R.A. Gitzen. 1999. Effects of sample size on kernel home range estimates. Journal of Wildlife Management: 63:739-747.

Severinghaus, C.A. 1949. Tooth development and wear as criteria of age in white-tailed deer. Journal of Wildlife Management 13:195-216.

Skogland, T. 1985. The effects of density-dependent resource limitations on the demography of wild reindeer. Journal of Animal Ecology 54:359-374.

Tierson, W.C., G.F. Mattfeld, R.W. Sage Jr., and D.F. Behrend. 1985. Seasonal movements and home ranges of white-tailed deer in the Adirondacks. Journal of Wildlife Management 49: 760-769.

Tilghman, N.G. 1989. Impacts of white-tailed deer on forest regeneration on northwestern Pennsylvania. Journal of Wildlife Management 53:524-532.

Van Horne, B. 1983. Density as a misleading indicator of habitat quality. Journal of Wildlife Management 47:893-901.

VerCauteren, K.C., J.A. Shivik, M.J. Lavelle. 2005. Efficacy of an animal-activated frightening device on urban elk and mule deer. Wildlife Society Bulletin 33(4): 1282-1287. 
VerCauteren, K.C., M.J. Lavelle, and S.E. Hyngstrom. 2006a. Fences and deer-damage management: a review of designs and efficacy. Wildlife Society Bulletin 34(1): 191-200.

VerCauteren, K.C., J.M. Gilsdorf, S.E. Hyngstrom, P.B. Fioranelli, J.A. Wilson, and S. Barras. 2006b. Green and blue lasers are ineffective for dispersing deer at night. Wildlife Society Bulletin 34(2): 371-374.

Vila, B., F. Torre, F. Guibal, and J.L. Martin. 2003. Growth and changes of young Picea sitchensis in response to deer browsing. Forest Ecology and Management 180:413-424.

Vreeland, J.K, D.R. Diefanbach, and B.D. Wallingford. 2004. Survival rates, mortality causes, and habitats of Pennsylvania white-tailed deer fawns. Wildlife Society Bulletin: 32(2): 542-553.

Wallingford, B.D., R.A. Lancia, and E.C. Soutiere. 1996. Antagonism of xylazine in whitetailed deer with intramuscular injection of yohimbine. Journal of Wildlife Diseases 32:399-402.

Weckerly, F.W., M.L. Kennedy, and S.W. Stephenson. 2005. Hunter-effort harvest-size relationships among hunt types of white-tailed deer. Wildlife Society Bulletin 33:13031311.

Wentworth, J.M., A.S. Johnson, P.E. Hale, and K.E. Kammermeyer. 1990a. Seasonal use of clearcuts and food plots by white-tailed deer in the southern Appalachians. Proceedings of the Southeastern Association of Fish and Wildlife Agencies 44:215-223.

Wentworth, J.M., A.S. Johnson, and P.E. Hale. 1990b. Influence of acorn use on nutritional status and reproduction of deer in the southern Appalachians. Proceedings of the Southeastern Association of Fish and Wildlife Agencies 44:142-154. 
White, G.C., and R.A. Garrott. 1990. Analysis of wildlife radio-tracking data. Academic Press, San Diego, CA.

White, G.C., and R.M. Bartmann. 1998. Effect of density reduction on overwinter survival of free-ranging mule deer fawns. Journal of Wildlife Management 62:214-225.

Williams, S.C., and A.J. DeNicola. 2002. Home range increase of lactating female white-tailed deer following herd reduction. Northeast Wildlife 57:29-38.

Winterstein, S.R., K.H. Pollock, and C.M. Buck. 2001. Analysis of survival data from radiotelemetry studies. Pages 351-380 in J.J. Millspaugh and J.M. Marzluff, editors. Radio tracking and animal populations. Academic Press, San Diego, CA, USA.

Worton, B.J. 1989. Kernel methods for estimating the utilization distribution in home-range studies. Ecology 70:164-168.

Worton, B.J. 1995. Using Monte Carlo simulation to evaluate kernel-based home range estimators. Journal of Wildlife Management 59:794-800.

Zar, J.H. 1999. Biostatistical analysis: $4^{\text {th }}$ edition. Prentice Hall, Upper Saddle River, NJ. 


\section{TABLES AND FIGURES}

Table 2.1: Telemetry locations (SE) collected from May 2006 through April 2008 on the MeadWestvaco Wildlife and Ecosystem Research Forest, West Virginia.

\begin{tabular}{|c|c|c|c|c|c|}
\hline \multirow[b]{2}{*}{ Year } & \multirow[b]{2}{*}{ Season } & \multicolumn{2}{|c|}{ Yearlings } & \multicolumn{2}{|c|}{ Adults } \\
\hline & & $n$ & $\overline{\bar{X}}$ locations & $n$ & $\overline{\bar{X}}$ locations \\
\hline \multirow[t]{4}{*}{$2006-2007$} & Summer & 5 & $45.0(6.0)$ & 16 & $46.3(2.7)$ \\
\hline & Fall & 5 & $37.6(0.5)$ & 15 & $35.9(0.9)$ \\
\hline & Winter & 4 & 39.3 (1.5) & 13 & $36.8(4.0)$ \\
\hline & Annual & 4 & $118.5(6.2)$ & 15 & $113.3(3.9)$ \\
\hline \multirow[t]{4}{*}{ 2007-2008 } & Summer & & & 21 & $59.0(2.3)$ \\
\hline & Fall & & & 13 & 35.5 (0.9) \\
\hline & Winter & & & 21 & $39.4(0.9)$ \\
\hline & Annual & & & 16 & 133.1 (4.3) \\
\hline
\end{tabular}


Table 2.2: Mean home-range and core-area (SE) size in hectares of female white-tailed deer on the MeadWestvaco Wildlife and Ecosystem Research Forest, West Virginia, 2006-2008.

\begin{tabular}{|c|c|c|c|c|c|c|c|}
\hline & & \multicolumn{3}{|c|}{ Adults } & \multicolumn{3}{|c|}{ Yearlings } \\
\hline Year & Season & $n$ & Home range & Core area & $n$ & Home range & Core area \\
\hline \multirow[t]{4}{*}{ 2006-2007 } & Summer & 16 & $272.6(63.6)$ & $47.0(18.8)$ & 5 & $500.1(94.5)$ & $42.1(7.6)$ \\
\hline & Fall & 15 & $293.2(56.6)$ & $37.8(8.2)$ & 5 & $469.6(167.0)$ & $53.8(22.4)$ \\
\hline & Winter & 13 & 266.5 (52.7) & $29.4(5.7)$ & 4 & 352.4 (99.6) & 38.8 (3.9) \\
\hline & Annual & 15 & $300.4(45.8)$ & $40.7(8.6)$ & 4 & $504.8(142.2)$ & 59.7 (18.3) \\
\hline \multirow[t]{4}{*}{ 2007-2008 } & Summer & 21 & $327.4(43.6)$ & $45.5(5.0)$ & & & \\
\hline & Fall & 13 & 297.5 (51.6) & 50.7 (10.8) & & & \\
\hline & Winter & 21 & 265.5 (26.5) & 36.5 (5.6) & & & \\
\hline & Annual & 16 & 329.3 (39.7) & $47.6(5.6)$ & & & \\
\hline
\end{tabular}


Table 2.3: Mean (SE) percent home-range (HR) and core-area (CA) overlap of female whitetailed deer on the MeadWestvaco Wildlife and Ecosystem Research Forest, West Virginia, 2006-2008.

\begin{tabular}{|c|c|c|c|c|c|c|}
\hline & \multicolumn{3}{|c|}{ Yearling maturing to adults } & \multicolumn{3}{|c|}{ Adults } \\
\hline Season & $n$ & HR & CA & $n$ & HR & CA \\
\hline Summer & 4 & $59(12)$ & $38(9)$ & 11 & $69(6)$ & $47(10)$ \\
\hline Fall & 4 & $65(4)$ & $61(18)$ & 6 & $75(7)$ & $82(8)$ \\
\hline Winter & 4 & $70(4)$ & 43 (19) & 8 & $68(5)$ & $32(8)$ \\
\hline Annual & 4 & $67(5)$ & $41(7)$ & 9 & $75(6)$ & $57(11)$ \\
\hline
\end{tabular}


Table 2.4: Adult survival rates and mortality sources for white-tailed deer on the MeadWestvaco Wildlife and Ecosystem Research Forest, West Virginia, 2006-2008.

\begin{tabular}{crrcrrrr}
\hline & & \multicolumn{2}{c}{ Survival } & & \multicolumn{2}{c}{ Mortalities } \\
\cline { 3 - 4 } \cline { 6 - 7 } Season & \multicolumn{1}{c}{$n$} & Rate & $95 \%$ CI & & Natural & Human \\
\hline Fall & 99 & 0.889 & $0.829-0.953$ & & 2 & 9 \\
Summer & 100 & 0.990 & $0.970-1.000$ & & 1 & 0 \\
Winter & 88 & 0.943 & $0.896-0.993$ & & 3 & 3 \\
Annual & & 0.830 & $0.721-0.946$ & & 6 & 12 \\
\hline
\end{tabular}


Figure 2.1: Kaplan-Meier survival functions for white-tailed deer by season on the MeadWestvaco Wildlife and Ecosystem Research Forest, 2006-2008. Dotted lines represent 95\% confidence limits.

Figure 2.2: Temporal trends in (A) total regeneration area on the MWERF, (B) antlered deer harvest during rifle season, (C) total black bear harvest, and (D) coyotes seen per 1000 hours of hunting from 1995-2007. B, C, and D are collective totals from Pocahontas, Randolph, Tucker, and Webster counties, West Virginia. 

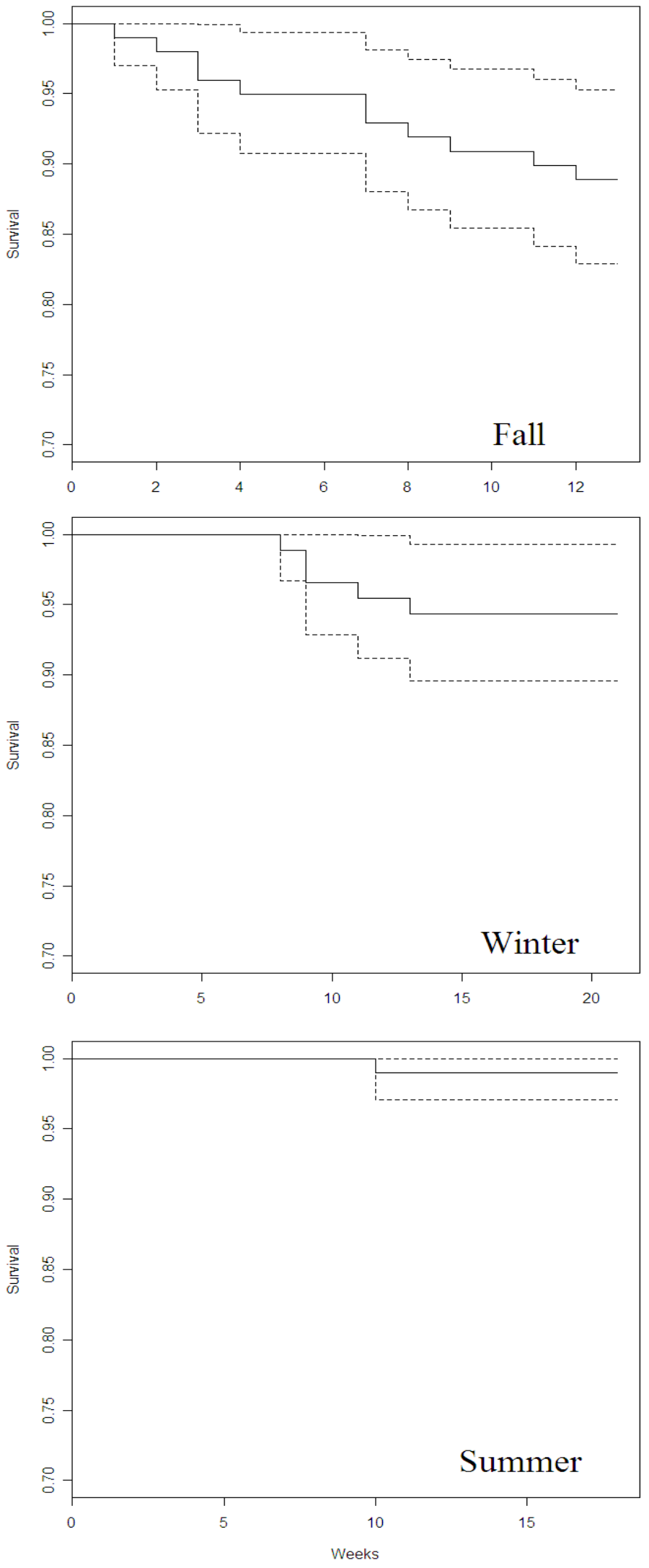

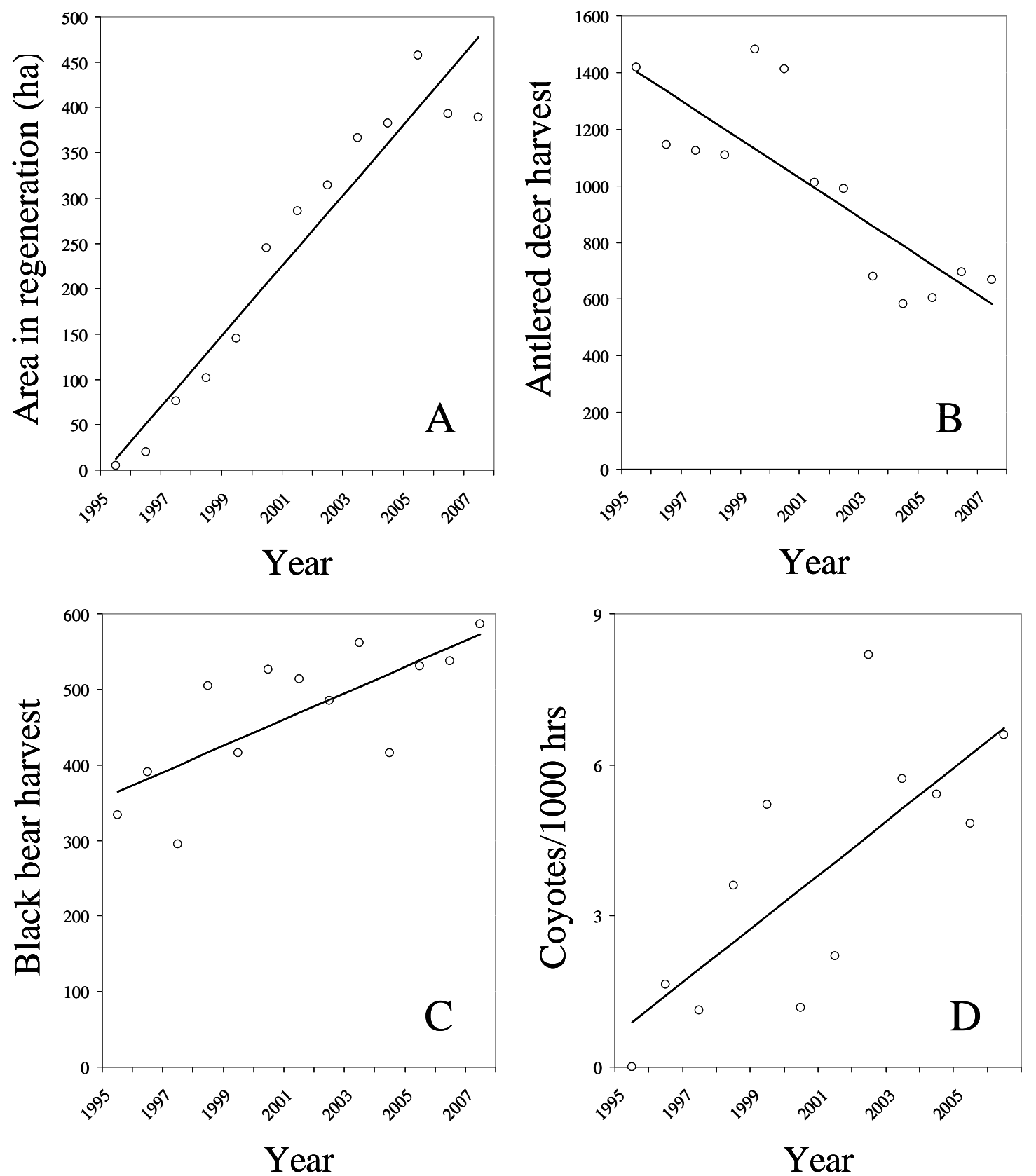


\section{CHAPTER 3}

\section{BROWSING PATTERNS OF WHITE-TAILED DEER IN THE CENTRAL APPALACHIANS FOLLOWING A DECLINE IN DENSITY ${ }^{1}$}

${ }^{1}$ Crimmins, S.M., J.W. Edwards, W.M. Ford, P.D. Keyser, and J.M. Crum. Formatted for the Northern Journal of Applied Forestry 
RH: Deer browsing patterns-Crimmins et al.

\section{BROWSING PATTERNS OF WHITE-TAILED DEER IN THE CENTRAL APPALACHIANS FOLLOWING A DECLINE IN DENSITY}

Shawn M. Crimmins, Division of Forestry and Natural Resources, West Virginia University, Morgantown, WV 26506

John W. Edwards, Division of Forestry and Natural Resources, West Virginia University, Morgantown, WV 26506

W. Mark Ford, USDA Forest Service, Northern Research Station, Parsons, WV 26287

Patrick D. Keyser, Department of Forestry, Wildlife, and Fisheries, University of Tennessee, Knoxville, TN 37996

James M. Crum, Wildlife Resources, West Virginia Division of Natural Resources, Elkins, WV 26241

John R. Brooks, Division of Forestry and Natural Resources, West Virginia University, Morgantown, WV 26506

Abstract: We examined browsing patterns of a white-tailed deer (Odocoileus virginianus) herd in central West Virginia that had experienced a severe decline in population size. Deer density on our study decreased approximately five fold $\left(12-20 / \mathrm{km}^{2}\right.$ to $\left.2-4 / \mathrm{km}^{2}\right)$ from 2001 to 2007.

The amount of early successional habitat on the study site doubled during the same time period. In summer 2007, we sampled 540 vegetation plots in and immediately adjacent to 12 regenerating clearcuts ranging in age from $0-5$ years post overstory removal. Woody browse was more abundant in clearcut interior than in clearcut edge or mature forest plots $(P<0.0001)$. Blackberry (Rubus spp.), birch (Betula spp.), black cherry (Prunus serotina), and greenbrier (Smilax spp.) were the most common species in clearcut interior and clearcut edge plots, with maple (Acer spp.) and greenbrier dominating mature forest plots. Woody browse abundance on the study site was greater $(P<0.05)$ than previously recorded at high deer densities. Browsing rates differed among plot types $(P<0.05)$, with clearcut edge plots having the highest browsing 
rates. Overall browsing rates were less than 5\%, compared to nearly $20 \%$ when deer population densities on the study site were substantially higher. Our results indicate that browsing rates have declined as deer population density declined. However, increases in the amount of early successional habitat may also have influenced changes in browsing rates.

Key words: Appalachians, browse, clearcut, Odocoileus virginianus, population density, regeneration, West Virginia, white-tailed deer

\section{Introduction}

Browsing of white-tailed deer (Odocoileus virginianus) in hardwood forest communities has many ecological impacts (Marquis and Brenneman 1981, deCalesta 1994, Horseley et al. 2003). Intensive browsing by deer reduces growth rates, ground cover, and species diversity of understory forbs (Alverson et al. 1988; Anderson 1994; Augustine and Frelich 1998; Rossell et al. 2005). Likewise, forest regeneration and diversity are negatively affected by browsing, with areas of high deer density exhibiting limited forest regeneration (Tilghman 1989; Horsley et al. 2003; Russel and Fowler 2004). In an examination of deer and forest community structure, Stromayer and Warren (1997) concluded that white-tailed deer herbivory was actually creating alternate steady state forests in much of the eastern United States. The resulting effects of deer herbivory on vegetative structure also can negatively affect wildlife. For example, groundnesting songbird abundance can be reduced due to decreased density and abundance of understory vegetation (McShea and Rappole 2000). McShea et al. (1995) observed that Kentucky warblers (Oporornis fomosus) shifted habitat selection and showed a decrease in breeding territory establishment where deer herbivory was high. In British Columbia, areas protected from Sitka black-tailed deer (O. hemionus sitkensis) browsing had higher densities of breeding songbirds, insects, and higher insect species diversity than areas with a history of deer 
browsing (Allombert et al. 2005a, 2005b). Herbivory by overabundant deer populations can lead to the complete removal of plant species from the forest communities that are selectively browsed (Alverson and Waller 1997; Anderson and Katz 1993).

Understanding the population density threshold beyond which deer herbivory negatively affects forest communities has been explored previously. In a 10-year study of deer herbivory in northern Pennsylvania, Horseley et al. (2003) found that deer densities exceeding $8 / \mathrm{km}^{2}$ were high enough to cause negative impacts on forest vegetation. Likewise, deCalesta (1994) found a density threshold between $7.9 / \mathrm{km}^{2}$ and $14.9 / \mathrm{km}^{2}$, above which richness and abundance of woody plant species was reduced. However, these studies were conducted in relatively small enclosures and did not examine herbivory patterns of free-ranging deer populations. Browsing patterns observed in these highly controlled studies may not be representative of patterns exhibited in free-ranging populations. Additionally, studies of enclosed deer cannot assess the potential effects of landscape-level changes in habitat structure or distribution. Marquis et al. (1992) suggested that increases in the amount of early successional habitat can buffer the impacts of overabundant deer, but such effects are difficult to assess in controlled enclosure studies such as those of deCalesta (1994) and Horseley et al. (2003).

In areas where deer are considered overabundant, a common management objective is to reduce deer densities to minimize negative affects on forest regeneration or other ecosystem components (Alverson et al. 1988). However, very little information exists on the browsing patterns of free-ranging white-tailed deer herds at low population density. In the eastern United States, most contemporary studies assessing browsing patterns of free-ranging deer have occurred in areas with moderate (Ford et al. 1993) or high deer densities (Campbell et al. 2006), and no studies have provided comparative information on browsing rates of free ranging 
populations in response to density reduction. Alverson et al. (1988) suggested that densities less than 4 deer $/ \mathrm{km}^{2}$ are necessary to maintain plant diversity in forested systems, however, they acknowledge that very little data exist and that research on such populations is needed to determine where or if thresholds of deer density exist with respect to browsing rates. Understanding the browsing patterns of free-ranging deer herds at varying population densities, particularly at low densities, is critical for proper forest management (Wentworth et al. 1990; Ford et al. 1993; Castleberry et al. 1999). Our objectives were to (1) examine availability and use of woody browse species in and adjacent to regenerating clearcuts in an area that recently experienced a severe decline in deer densities and a concomitant increase in early successional habitat, and (2) compare our findings to those previously found on the same area when deer densities were higher.

\section{Study Area and Methods}

We conducted our study on the MeadWestvaco Wildlife and Ecosystem Research Forest (MWERF) in central Randolph County, West Virginia during summer 2007 (Fig. 3.1). The 3,260-ha MWERF occurs in the Unglaciated Allegheny Mountain and Plateau physiographic province (Fenneman 1938) and ranges in elevation from 700 to 1200 meters. The MWERF is characterized by steep slopes, broad ridge-tops and narrow valleys with small, high-gradient headwater streams. Average annual precipitation on the site ranges between 170 and $190 \mathrm{~cm}$ with an average snowfall $>300 \mathrm{~cm} /$ year (National Oceanic and Atmospheric Administration, 1998-2002). The MWERF was originally harvested in the early 1900’s and is comprised primarily of second-growth hardwood-northern hardwood forests (Clarkston 1993). Forest communities of the MWERF were dominated by American beech (Fagus grandifolia), red maple (Acer rubrum), sugar maple (A. saccharum), yellow-poplar (Liriodendron tulipfera), and black 
cherry (Prunus serotina). Other common species included yellow birch (Betula allegheniensis) American basswood (Tilia americana), black birch (B. lenta), and northern red oak (Ouercus rubra). High elevation areas are dominated by red spruce (Picea rubens) and eastern hemlock (Tsuga canadensis) communities. Throughout much of the area, the understory is dominated by greenbrier (Smilax spp.) and mountain laurel (Kalmia latifolia), with dense rosebay rhododendron (Rhododendron maximum) prevalent along riparian areas. Since 2000, more than 500 ha of forest have been harvested on the MWERF, of which 75\% was clearcut, with the remaining 25\% in deferment, diameter-limit, and marked-selection harvests. Even-aged harvests averaged 15 ha in size since the mid-1990’s. Population surveys conducted in October 2005 and 2007 indicate that the white-tailed deer population on the MWERF has stabilized at approximately 2-4 deer $/ \mathrm{km}^{2}$, which is substantially lower than on the MWERF at the time of previous research (12-20 deer/ km²) examining deer browsing patterns in 2001 (Langdon 2001; Campbell et al. 2006, Miller 2008). Regenerating (0-5 years post harvest) clearcuts comprised approximately 8\% of the MWERF in 2001 (Campbell et al. 2006), and increased to > 12\% of the MWERF at the time of our study (Fig. 3.2).

We selected 12 regenerating clearcuts ranging in age from $0-5$ years post harvest to examine availability and use of woody browse by white-tailed deer. We defined age classes based on the number of complete growing seasons (years) since harvest (Campbell et al. 2006). Following Ford et al. (1993) and Campbell et al. (2006), we systematically established $150.5-\mathrm{m}^{2}$ plots at 50-m intervals within each clearcut along the perimeter of the clearcut with a randomly assigned starting point. For each plot, we established a paired plot $20 \mathrm{~m}$ into the clearcut interior perpendicular to the edge of the clearcut, and a second paired plot $20 \mathrm{~m}$ into the adjacent mature forest (Fig. 3.3). Within each plot, we identified all woody species and quantified the number of 
woody twig tips available for browsing (i.e. $\leq 1.5 \mathrm{~m}$ from the ground) by species group following Ford et al. (1993). These methods were similar to those used by Campbell et al. (2006) and allowed for general comparisons between results. We calculated percent of available twigs browsed (PATB), relative abundance (RA), and relative use (RU) for each species following Strole and Anderson (1992) as: PATB = (number of twigs browsed for a species / number of twigs available for a species) $* 100, \mathrm{RA}=$ (number of twigs available for a species $/$ number of twigs available for all species) $* 100$, and $\mathrm{RU}=$ (number of twigs browsed for a species / total number of twigs browsed for all species ) * 100 .

We compared woody browse abundance among plot types (i.e., clearcut interior, clearcut edge, mature forest) using analysis of variance (ANOVA). We pooled data across clearcut age classes prior to analysis and considered each plot to be an individual sampling unit. Our ANOVA model included plot type ( $n=3)$ as a treatment effect. We used Tukey's honestly significant difference (HSD) as a multiple range test. We compared percent use (PATB) among plot types for each species and across all species using pair-wise chi-square tests. We determined browsing selection for individual species across plot types using chi-square tests between the binomial probabilities of relative use and relative abundance for each species. When appropriate we used a Bonferroni correction to maintain experiment-wise error rates (Sokal and Rohlf 1995). We assigned species as browsed at rates greater than, less than, or equal to available if relative use values were higher, lower, or statistically equal to relative abundance values. We compared woody browse abundance between study periods (2001 and 2007) for clearcut interior and mature forest plots by comparing the $95 \%$ standard errors of our results to those of Campbell et al. (2006). We also compared PATB values in clearcut interior and mature forest plots between study periods for eight browse species that were examined by Campbell et 
al. (2006). We were unable to compare woody browse abundance or use in clearcut edge plots between study periods, as they were not sampled by Campbell et al. (2006). All statistical tests were conducted using SAS (SAS Institute, 2001) with $\alpha=0.10$.

\section{Results}

Clearcut interior and clearcut edge plots both produced abundant woody browse (Table 3.1). Total woody browse abundance for all species differed by plot type $(F=63.31, P<0.0001)$. Mature forest plots produced less woody browse than clearcut interior or clearcut edge plots, with clearcut interior plots producing the most of the three plot types (Table 3.1). Most species were least abundant in mature forest plots with the exception of maple $(F=32.44, P<0.0001)$ and American beech $(F=4.55, P=0.011)$. Of the 13 species recorded, only greenbrier $(F=$ 1.74, $P=0.176)$, blackgum $(F=1.73, P=0.178)$, and eastern hemlock $(F=0.45, P=0.64)$ did not differ between plot types.

Percent of available twigs browsed (PATB) was similar between clearcut interior and mature forest plots $(P=0.388)$ but was significantly higher $(P<0.0001)$ in clearcut edge plots than in either mature forest or clearcut interior plots (Table 3.1). With the exception of yellow-poplar and maple, all species had their highest PATB values in clearcut edge or mature forest plots (Table 3.1). Of the 13 species and species groups, 3 were browsed at rates equal to their availability when pooled across plot types (Table 3.2). Blackberry $(P=0.0005)$, birch $(P<$ 0.0001), pin cherry $(P=0.0005)$, sassafras $(P<0.0001)$, American beech $(P=0.026)$ and blackgum $(P=0.034)$ were browsed at rates higher than their respective availabilities. Greenbrier $(P<0.0001)$, yellow-poplar $(P<0.0001)$, maple $(P=0.093)$, and the other species groups $(P=0.0706)$ were browsed at rates lower than their respective availabilities. 
Woody browse abundance recorded in 2007 was significantly higher $(P<0.05)$ in mature forest plots than previously found in 2001 at high population density (Fig. 3.4A). Abundance also was higher in clearcut interior plots, but the relation was not significant $(P>0.05)$ (Fig. 3.4A). Total PATB values across all species were substantially lower than previously reported in 2001 for clearcut interior and mature forest plots (Fig. 3.4B). PATB values for species examined in both study periods were lower than previously reported in mature forest plots (Fig. 3.5A). PATB values also were lower in 2007 than previously reported in 2001 for seven species in clearcut interior plots, with sassafras being the only species that was browsed at higher rates during our study (Fig. 3.5B).

\section{Discussion}

Previous studies of white-tailed deer browsing rates in the southern Appalachians (Ford et al. 1993) and coastal plain of South Carolina (Castleberry et al. 1999) documented overall summer browsing rates (PATB) of approximately $5 \%$ in areas of moderate deer densities $\left(6-8 / \mathrm{km}^{2}\right)$. However, Campbell et al. (2006) reported browsing rates > 20\% on the MWERF in 2001 when deer densities were estimated at $20 / \mathrm{km}^{2}$. Our overall browsing rate of $4.4 \%$ is similar to Ford et al. (1993) and Castleberry et al. (1999), who concluded that browsing at this level was not impacting forest regeneration. Campbell et al. (2006) concluded that the high browsing rates they observed on the MWERF would likely alter forest composition on the MWERF if it persisted. Miller (2008) reported that browsing rates in regenerating clearcuts on the MWERF decreased annually from 2001 to 2004 and concluded that this may have been due to increases in the abundance of woody browse across the landscape as a result of increased timber harvest (Fig. 3.2) and that a threshold of sufficient regeneration units to overcome herbivory may have been reached. However, Miller (2008) did not account for potential changes deer population density 
on the MWERF, suggesting that the changes in observed browsing rates may not have been the direct result of forest management. We observed an overall increase in woody browse abundance in clearcut interior (50.2 stems/0.5 m² vs. 44.6 stems $/ 0.5 \mathrm{~m}^{2}$ ) and mature forest (18.9 stems $/ 0.5 \mathrm{~m}^{2}$ vs. 10.2 stems $/ 0.5 \mathrm{~m}^{2}$ ) plots versus Campbell et al. (2006). At the time Campbell et al. (2006) conducted their study approximately 7\% of the MWERF was in regenerating clearcuts, whereas $>12 \%$ of the area was such at the time of our study. This increase in woody browse across the study area limits our ability to attribute observed changes in abundance or use of browse exclusively to changes in deer population density. Although there may have been observer related differences between our study and Campbell et al. (2006), this likely had little effect on the general trends we observed between the two study periods.

Campbell et al. (2006) suggested that low browsing rates of American beech would lead to a larger overstory component of this species and that high browsing rates of birch would lead to its decreased abundance in future stands. Miller (2008) observed low browsing rates of birch and a subsequent increase in its availability on the MWERF from 2001 to 2004, suggesting that birch could become an important overstory component in the future. We observed low browsing rates for both species (<5\%) and found relatively little American beech in our study plots, indicating that future stands may have higher abundance of birch than predicted by Campbell et al. (2006). The predictions of Campbell et al. (2006) were based on the assumption that deer population density and browsing rates would remain at high levels. Moreover, variation in previous stand histories may have led to differences in initial species composition between clearcuts that we sampled and those sampled by Campbell et al. (2006) and Miller (2008). In addition to these factors, our results may have been slightly biased toward higher browsing rates because most of the clearcuts we sampled were on ridges or in higher elevation areas of the study 
site, which has been shown to affect browsing rates on the MWERF (Campbell et al. 2006). McGill et al. (2003) found that deer herbivory reduced the abundance of pin cherry (Prunus pennsylvanicus) seedlings on the MWERF, in contrast pin cherry was relatively abundant in our plots despite it being browsed in greater proportion than its availability. These findings highlight the dynamic nature of deer browsing and how shifts in population density, and potentially habitat structure, can influence herbivory and forest regeneration patterns. The differences in our observed results and the predictions of Campbell et al. (2006) and Miller (2008) may indicate that using forest stand (e.g. individual clearcut) based studies of herbivory to predict landscapelevel browsing patterns and effects on forest regeneration and structure may not be appropriate if confounding factors, such as population density and habitat structure, are not explicitly accounted for. Our findings also indicate that regeneration patterns of individual species may limit the utility of landscape-level predictions of forest dynamics based on plot-level measurements that do not incorporate factors that may influence successional dynamics (e.g. shade, topography, slope).

It has been suggested that increasing timber harvest, thereby increasing the amount of available woody browse, is a viable means of reducing browsing pressure to the point that forest regeneration is not impacted by deer (Marquis et al. 1992; Ford et al. 1993; Kalen 2005; Miller 2008). However, the negative effects of deer herbivory may not be as substantial in forest regeneration areas characterized by low deer densities (Tilghman 1989; Ford et al. 1993). Deer densities less than $4 / \mathrm{km}^{2}$ have been suggested as necessary to ensure that diverse plant communities and healthy reproduction and regeneration of northern hardwood forest communities can persist (Alverson et al. 1988). Our study, which is to our knowledge the only one to provide comparative data on browsing rates in an area that has seen both an increase in the 
amount of timber harvest and a reduction in deer densities, supports the conclusions of previous researchers that these techniques can reduce deer browsing in forest regeneration areas, particularly when combined. However, we recognize our inability to determine if one factor (deer population density or increased abundance of early successional habitat) contributed to our observed decrease in herbivory rates more than the other or if the two contributed equally. Despite this, we believe that our results suggest that a combination of increased timber harvest and decreased deer densities is likely to improve forest regeneration by reducing browsing rates.

\section{Literature Cited}

ALLISON, T.D. 1990. The influence of deer browsing on the reproductive biology of Canada yew I. direct effects on pollen, ovules, and seed production. Oecologia: 83: 523-529

Allombert, S., A.J. Gaston, AND J.L. MarTin. 2005a. A natural experiment on the impact of overabundant deer on songbird populations. Biological Conservation: 126(1): 1-13.

$\longrightarrow,-$, and $\longrightarrow$ 2005b. A natural experiment on the impact of overabundant deer on forest invertebrates. Conservation Biology. 19(6): 1917-1929.

ALVERSON, W.S., D.M WALLER, AND S.L. SOlHeim. 1988. Forests to deer: edge effects in northern Wisconsin. Conservation Biology: 2: 348-358.

— and — 1997. Deer populations and the widespread failure of hemlock regeneration in northern forests. Pp. 280-297 in The science of overabundance: deer ecology and population management, W.J. McShea, H.B. Underwood, and J.H. Rappole (eds.). Smithsonian Institution Press, Washington, DC.-

ANDERSON, R.C. 1994. Height of white-flowered trillium (Trillium grandiflorum) as an index of deer browsing intensity. Ecological Applications: 4: 104-109. 
— , AND O. LOUCKs. 1979. White-tailed deer (Odocoileus virginianus) influence upon structure and composition of Tsuga canadensis forests. Journal of Applied Ecology: 16: 855-861.

-, AND A.J. KATZ. 1993. Recovery of browse-sensitive tree species following release from white-tailed deer Odocoileus virginianus Zimmerman browsing pressure. Biological Conservation 63:203-208.

Augustine, D.J., AND L.E. FreLiCH. 1998. Effects of white-tailed deer on populations of an understory forb in a fragmented deciduous forest. Conservation Biology: 12(5): 995-1004.

BELLINGHAM, P.J., AND C.N. ALLAN. 2003. Forest regeneration and the influences of white-tailed deer (Odocoileus virginianus) in cool temperate New Zealand rain forests. Forest Ecology and Management: 175: 71-86.

CAMPBeLL, T.A., B.R. LASETER, W.M. Ford, R.H. Odom, AND K.V. MilLer. 2006. Abiotic factors influencing deer browsing in West Virginia. Northern Journal of Applied Forestry 23:20-26.

CASTLEBerRy, S.B., W.M. Ford, K.V. MilleR, AND W.P. SMith. 1999. White-tailed deer browse preferences in a southern bottomland hardwood forest. Southern Journal of Applied Forestry 23:78-82.

Clarkston, R.B. 1993. Destruction of the upland forest by lumbering and fire. P. 35-46 in Upland forest of West Virginia, Stephenson, S.L. (ed). McClain Printing Company, Parsons, WV.

DECALESTA, D.S. 1994. Effect of white-tailed deer on songbirds within managed forests in Pennsylvania. Journal of Wildlife Management 58:711-718. 
FEnNEmAn, N.M. 1938. Physiography of the eastern United States. McGraw-Hill, New York, NY. 714 p.

Ford, W.M., A.S. Johnson, P.E. HALE, AND J.M. WenTWORTH. 1993. Availability and use of spring and summer woody browse by deer in clearcut and uncut forests of the Southern Appalachians. Southern Journal of Applied Forestry 17:116-119.

FRELICH L.E., AND C.G. LORIMER. 1985. Current and predicted long-term effects of deer browsing in hemlock forests in Michigan, USA. Biological Conservation 34: 99-120.

HEALY, W.M. 1997. Influence of deer on the structure and composition of oak forests in central Massachusetts. Pages 249-266 in W.J. McShea, H.B. Underwood, and J.H. Rappole, editors. The science of overabundance: deer ecology and management. Smithsonian Institution Press, Washington, D.C., USA.

Horseley, S.B., S.L. StOUT, AND D.S. DECALESTA. 2003. White-tailed deer impacts on the vegetation dynamics of a northern hardwood forest. Ecological Applications 13:98-118.

KALEN, C. 2005. Deer browsing and impact on forest development. Journal of Sustainable Forestry 21:51-62.

LANGDON, C.A. 2001. A comparison of white-tailed deer population estimation methods in West Virginia. M.Sc. thesis, West Virginia Univ., Morgantown, WV. 119 p.

MARQUis, D.A., AND R. BRENNEMAN. 1981. The impact of deer on forest vegetation in Pennsylvania. US Forest Service General Technical Report, NE-65, 11 p.

—, R.L. ERNST, AND S.L. STOUT. 1992. Prescribing silvicultural treatments in hardwood stands of the Alleghenies. USFS General Technical Report, NE-96. 101 p.

MCGill, D.W., R.J. COLLINS, AND W.P. CARSON. 2003. Response of pin cherry to fire, canopy disturbance, and deer herbivory on the Westvaco Wildlife and Ecosystem Research Forest. 
Pages 282-290 in J.W. Van Sambeek, J.O. Dawson, F. Ponder Jr., E.F. Loewenstein, and S. James, editors. $13^{\text {th }}$ Central Hardwood Forest Conference. United States Department of Agriculture, Forest Service, General Technical Report NC-234: 1-565.

McSHEA, W.J., AND G. SCHWEDE. 1993. Variable acorn crops: responses of white-tailed deer and other mast consumers. Journal of Mammalogy: 74: 999-1006.

—, M.V. McDonald, G.E. Morton, R. Meier, And J.H. Rappole. 1995. Long-term monitoring of Kentucky Warbler habitat selection. Auk 112: 375-381.

_ AND J.H. RAPPOLE. 2000. Managing the abundance and diversity of breeding bird populations through manipulation of deer populations. Conservation Biology 14:11611170.

MiLLER, B.F. 2008. Social structuring of a central Appalachian deer herd and a test of localized management. Ph.D. dissertation, University of Georgia, Athens, GA. 137 p.

Nugent, G., W. Fraser, AND P. SweetapPle. 2001. Top down or bottom up? Comparing the impacts of introduced arboreal possums and 'terrestrial' ruminants on native forests in New Zealand. Biological Conservation: 99: 65-80.

Rossell, C.R. JR., B. GORSIRA, AND S. PATCH. 2005. Effects of white-tailed deer on vegetation structure and woody seedling composition in three forest types on the Piedmont Plateau. Forest Ecology and Management: 210: 415-424.

RUSSELL, F.L., AND N.L. FOWLER. 2004. Effects of white-tailed deer on the population dynamics of acorns, seedling and small saplings of Quercus bucleyi. Plant Ecology: 173: 59-72.

SOKAL, J.H., AND F.J. RoHLF. 1995. Biometry. Third edition. W.H. Freeman, New York, NY, USA. 
StEINER, K.C. 1996. Autumn predation of northern red oak seed crops. Pages 489-494 in K.W. Gottschalk, and S.L. Fosbroke, editors. $10^{\text {th }}$ Central Hardwood Forest Conference. United States Department of Agriculture, Forest Service, General Technical Report NE-197: 1577.

StROLE, T.A., AND R.C. ANDERSON. 1992. White-tailed deer browsing: species preferences and implications for central Illinois forests. Natural Areas Journal 12:139-144.

TiLGHMAN, N.G. 1989. Impacts of white-tailed deer on forest regeneration in northwestern Pennsylvania. Journal of Wildlife Management 53:524-532.

Wentworth, J.M, A.S. Johnson, P.E. HALE, AND K.E. KAMmERMEYer. 1990. Seasonal use of clearcuts and food plots by white-tailed deer in the Southern Appalachians. Proceedings of the Southeastern Association of Fish and Wildlife Agencies 44:215-223.

ZAR, J.H. 1999. Biostatistical Analysis: $4^{\text {th }}$ edition. Prentice Hall, Upper Saddle River, NJ. 
Table 3.1: Mean (SE) availability and use of woody browse species in clearcut interior, clearcut edge, and mature forest plots on the

MeadWestvaco Wildlife and Ecosystem Research Forest, Randolph County, West Virginia during summer 2007.

\begin{tabular}{|c|c|c|c|c|c|c|}
\hline \multirow[b]{2}{*}{ Species } & \multicolumn{2}{|c|}{ Clearcut interior $^{\mathrm{a}}$} & \multicolumn{2}{|c|}{ Clearcut edge $^{\mathrm{a}}$} & \multicolumn{2}{|c|}{ Mature forest $^{\mathrm{a}}$} \\
\hline & $\begin{array}{c}\text { Available }^{\mathrm{b}} \\
{\text { (twigs } / 0.5 \mathrm{~m}^{2} \text { ) }}\end{array}$ & $\begin{array}{c}\text { Use }^{c} \\
\text { (\% browsed) }\end{array}$ & $\begin{array}{c}\text { Available }{ }^{\mathrm{b}} \\
\text { (twigs } / 0.5 \mathrm{~m}^{2} \text { ) }\end{array}$ & $\begin{array}{c}\text { Use }^{\mathrm{c}} \\
\text { (\% browsed) }\end{array}$ & $\begin{array}{c}\text { Available }^{\mathrm{b}} \\
\text { (twigs/0.5 m²) }\end{array}$ & $\begin{array}{c}\text { Use }^{\mathrm{c}} \\
\text { (\% browsed) }\end{array}$ \\
\hline Blackberry (Rubus spp.) & $22.04(2.24) \mathrm{A}$ & $4.18 \mathrm{a}$ & $12.56(1.51) \mathrm{B}$ & $6.80 \mathrm{~b}$ & $0.11(0.07) \mathrm{C}$ & $0.00 \mathrm{ab}$ \\
\hline Birch (Betula spp.) & $6.81(1.04) \mathrm{A}$ & $4.57 \mathrm{a}$ & $5.20(0.91) \mathrm{A}$ & $8.33 \mathrm{~b}$ & $0.44(0.13) \mathrm{B}$ & $10.00 \mathrm{~b}$ \\
\hline Black cherry (Prunus serotina) & $4.12(0.81) \mathrm{A}$ & $3.51 \mathrm{a}$ & $1.69(0.45) \mathrm{B}$ & $4.93 \mathrm{a}$ & $0.25(0.10) \mathrm{B}$ & $0.00 \mathrm{~b}$ \\
\hline Greenbrier (Smilax spp.) & $3.77(0.85) \mathrm{A}$ & $0.89 \mathrm{a}$ & $5.74(0.75) \mathrm{A}$ & $1.45 \mathrm{ab}$ & $5.53(0.96) \mathrm{A}$ & $1.65 \mathrm{~b}$ \\
\hline Yellow-poplar (Liriodendron tulipifera) & $2.77(0.43) \mathrm{A}$ & $0.40 \mathrm{a}$ & $0.76(0.17) \mathrm{B}$ & $0.00 \mathrm{a}$ & $0.28(0.11) \mathrm{B}$ & $0.00 \mathrm{a}$ \\
\hline Maple (Acer spp.) & $2.62(0.56) \mathrm{A}$ & $7.64 \mathrm{a}$ & $2.25(0.42) \mathrm{A}$ & $4.20 \mathrm{~b}$ & $8.84(0.87) \mathrm{B}$ & $2.39 \mathrm{c}$ \\
\hline Pin cherry (Prunus pensylvanica) & $2.33(0.56) \mathrm{A}$ & $6.90 \mathrm{a}$ & $1.66(0.53) \mathrm{A}$ & $7.72 \mathrm{a}$ & $0.09(0.06) \mathrm{B}$ & $0.00 \mathrm{~b}$ \\
\hline Other ${ }^{\mathrm{c}}$ & $1.87(0.46) \mathrm{A}$ & 0.59 a & $0.59(0.14) \mathrm{B}$ & $4.67 \mathrm{ab}$ & $1.34(0.44) \mathrm{AB}$ & $5.39 \mathrm{~b}$ \\
\hline Oak (Quercus spp.) & $1.75(0.45) \mathrm{A}$ & $4.13 \mathrm{a}$ & $0.48(0.26) \mathrm{B}$ & $0.00 \mathrm{a}$ & $0.17(0.08) \mathrm{B}$ & $12.90 \mathrm{~b}$ \\
\hline Sassafras (Sassafras albidum) & $0.87(0.25) \mathrm{A}$ & $14.01 \mathrm{a}$ & $0.51(0.28) \mathrm{AB}$ & $4.40 \mathrm{~b}$ & $0.08(0.06) \mathrm{B}$ & 28.57 a \\
\hline American beech (Fagus grandifolia) & $0.77(0.30) \mathrm{AB}$ & $0.00 \mathrm{a}$ & $0.11(0.06) \mathrm{A}$ & $5.00 \mathrm{~b}$ & $1.34(0.40) \mathrm{B}$ & $10.74 \mathrm{~b}$ \\
\hline Blackgum (Nyssa sylvatica) & $0.27(0.15) \mathrm{A}$ & $4.17 \mathrm{a}$ & $0.05(0.03) \mathrm{A}$ & $22.22 \mathrm{ab}$ & $0.08(0.04) \mathrm{A}$ & $21.43 \mathrm{~b}$ \\
\hline Eastern hemlock (Tsuga canadensis) & $0.16(0.11) \mathrm{A}$ & $0.00 \mathrm{a}$ & $0.35(0.21) \mathrm{A}$ & $7.94 \mathrm{a}$ & $0.16(0.16) \mathrm{A}$ & $0.00 \mathrm{a}$ \\
\hline All species & $50.16(2.51) \mathrm{A}$ & 3.99 a & $31.95(1.81) \mathrm{B}$ & $5.55 \mathrm{~b}$ & $18.93(1.44) \mathrm{C}$ & $3.32 \mathrm{a}$ \\
\hline
\end{tabular}

${ }^{\mathrm{b}}$ Available means in the same row followed by the same upper case letter were statistically similar $(P>0.10)$

${ }^{\mathrm{c}}$ Use percentages (PATB) in the same row followed by the same lower case letter were statistically similar $(P>0.10)$

${ }^{\mathrm{d}}$ Includes cucumbertree (Magnolia acuminata), American basswood (Tilia americana), mountain magnolia (Magnolia fraseri), witch-hazel (Hamamelis

virginiana), red spruce (Picea rubens), and wild grape (Vitis spp.) 
Table 3.2: Percent of available twigs browsed (PATB), relative abundance (RA), relative use (RU), and white-tailed deer selection for woody browse species on the MeadWestvaco Wildlife and Ecosystem Research Forest, 2007.

\begin{tabular}{lcrrc}
\hline \multicolumn{1}{c}{ Species } & PATB & RA & RU & Use $^{\mathrm{a}}$ \\
\hline Blackberry (Rubus spp.) & 5.12 & 34.37 & 40.40 & Greater \\
Birch (Betula spp.) & 6.33 & 12.33 & 17.93 & Greater \\
Pin cherry (Prunus pensylvanica) & 7.07 & 4.04 & 6.57 & Greater \\
Sassafras (Sassafras albidum) & 11.45 & 1.44 & 3.79 & Greater \\
American Beech (Fagus grandifolia) & 6.73 & 2.20 & 3.40 & Greater \\
Blackgum (Nyssa sylvatica) & 9.86 & 0.39 & 0.88 & Greater \\
Oak (Quercus spp.) & 3.94 & 2.38 & 2.15 & Equal \\
Eastern Hemlock (Tsuga canadensis) & 4.13 & 0.67 & 0.63 & Equal \\
Black cherry (Prunus serotina) & 3.76 & 5.99 & 5.18 & Equal \\
Greenbrier (Smilax spp.) & 1.39 & 15.08 & 4.80 & Less \\
Yellow-poplar (Liriodendron tulipifera) & 0.29 & 3.77 & 0.25 & Less \\
Maple (Acer spp.) & 3.69 & 13.57 & 11.49 & Less \\
Other & 2.92 & 3.77 & 2.53 & Less \\
\hline
\end{tabular}

${ }^{\mathrm{a}}$ Indicates RU values were significantly greater than, less than, or equal to RA values 


\section{FIGURE LEGEND}

Figure 3.1: Twelve clearcuts sampled for woody browse on MeadWestvaco Wildlife and Ecosystem Research Forest, Randolph County, West Virginia, 2007.

Figure 3.2: Proportion of MWERF in early successional (0-5 years post harvest) habitat on the MeadWestvaco Wildlife and Ecosystem Research Forest from 1996-2007.

Figure 3.3: Layout of browse survey plots MeadWestvaco Wildlife and Ecosystem Research Forest, 2007.

Figure 3.4: Woody browse abundance (A) and percent use (B) between study periods on the MeadWestvaco Wildlife and Ecosystem Research Forest. Solid bars represent data from 2001 (Campbell et al. 2006), hatched bars represent data from 2007. Error bars represent \pm one standard error.

Figure 3.5: Percent of available twigs browsed (PATB) for selected browse species in mature forest (A) and clearcut interior (B) plots between study periods on the MeadWestvaco Wildlife and Ecosystem Research Forest. Solid bars represent data from 2001 (Campbell et al. 2006), hatched bars represent data from 2007. 


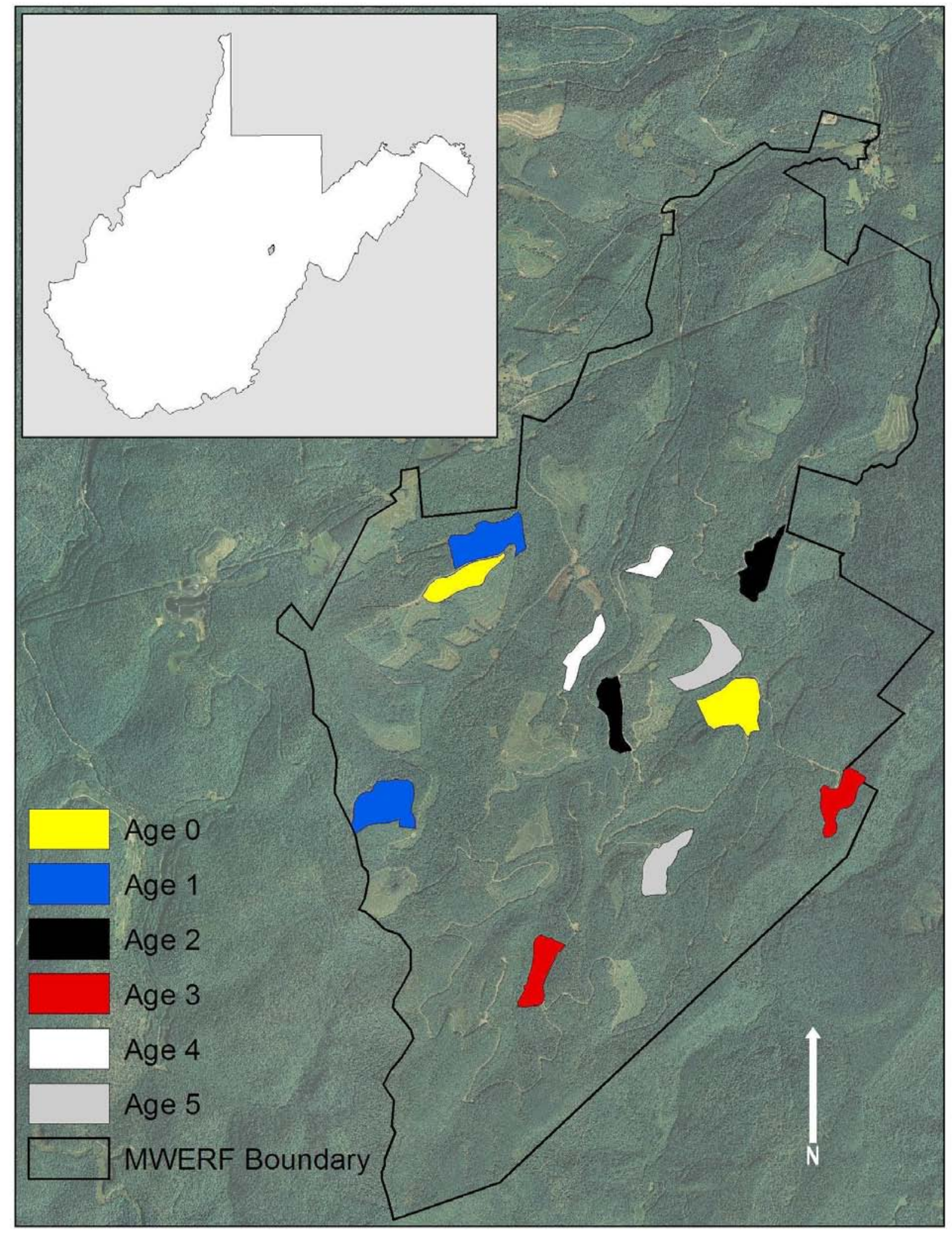




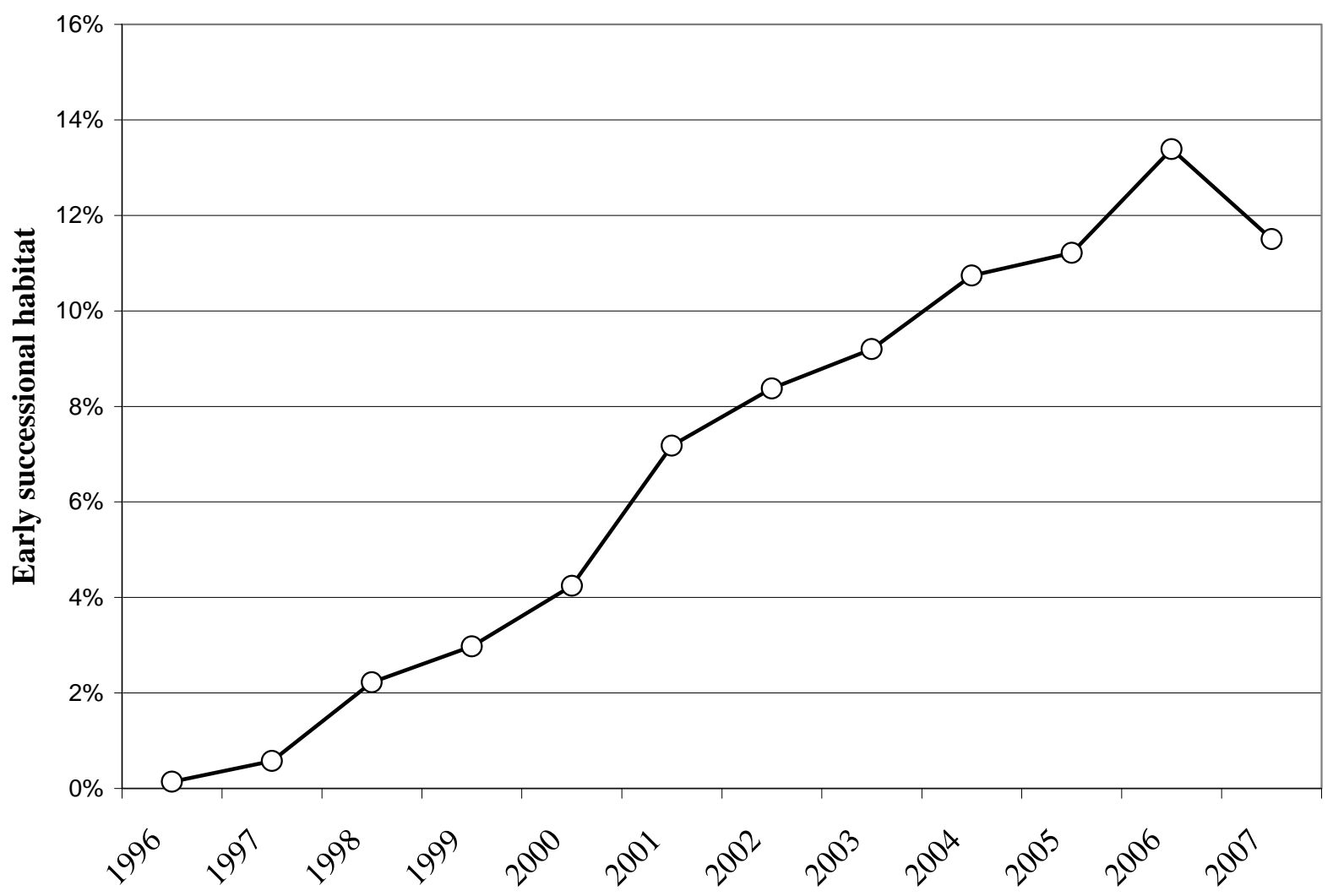

82 


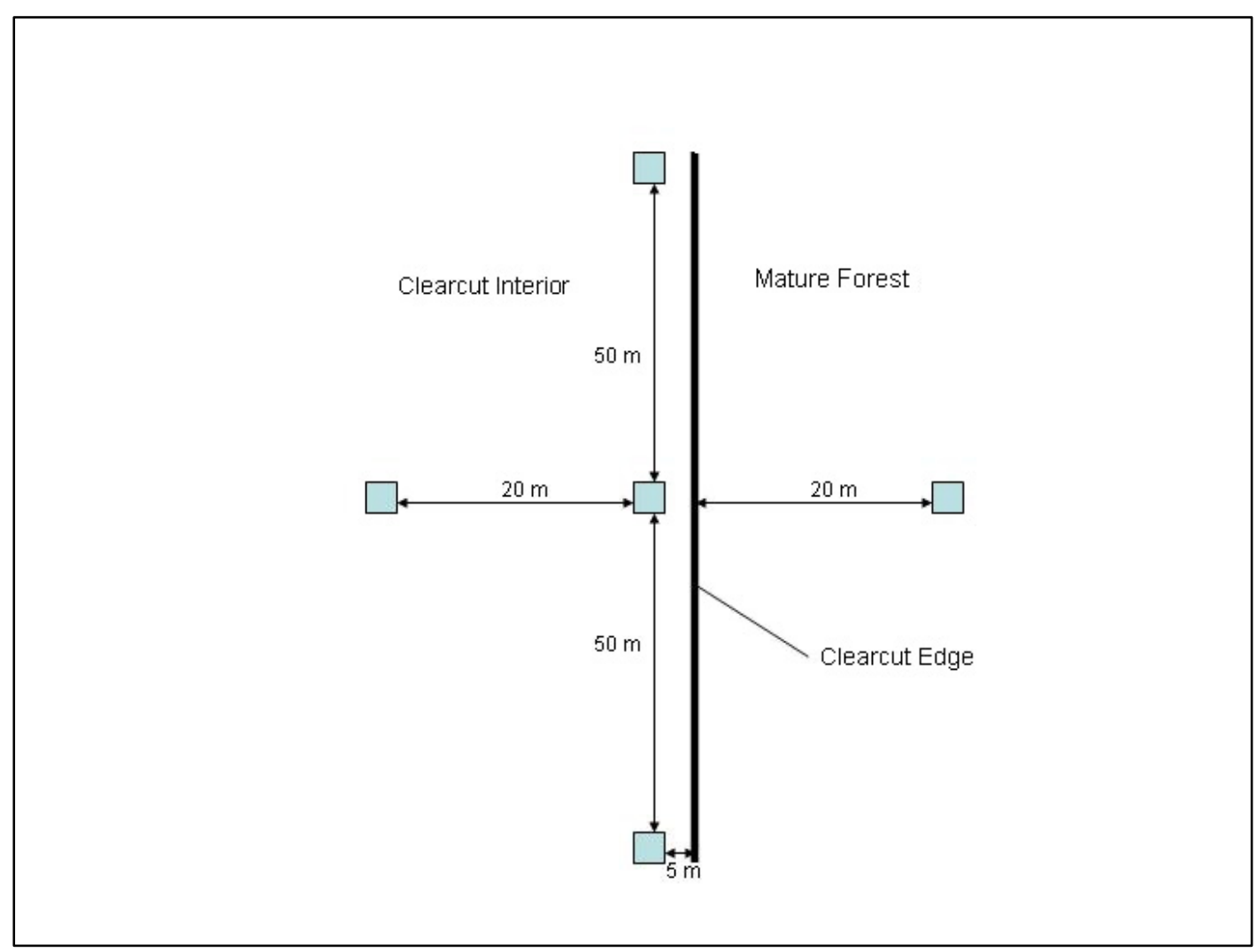



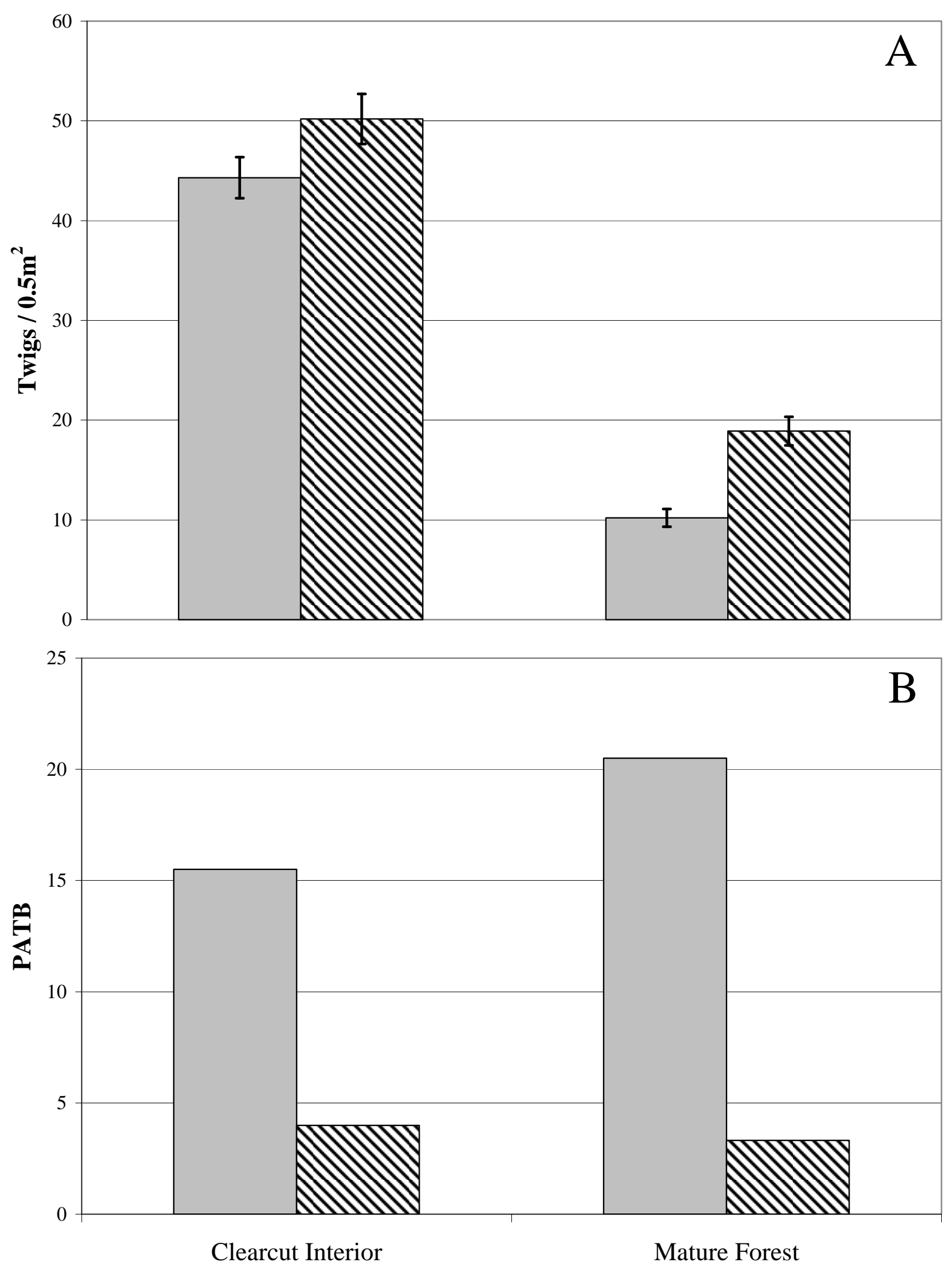

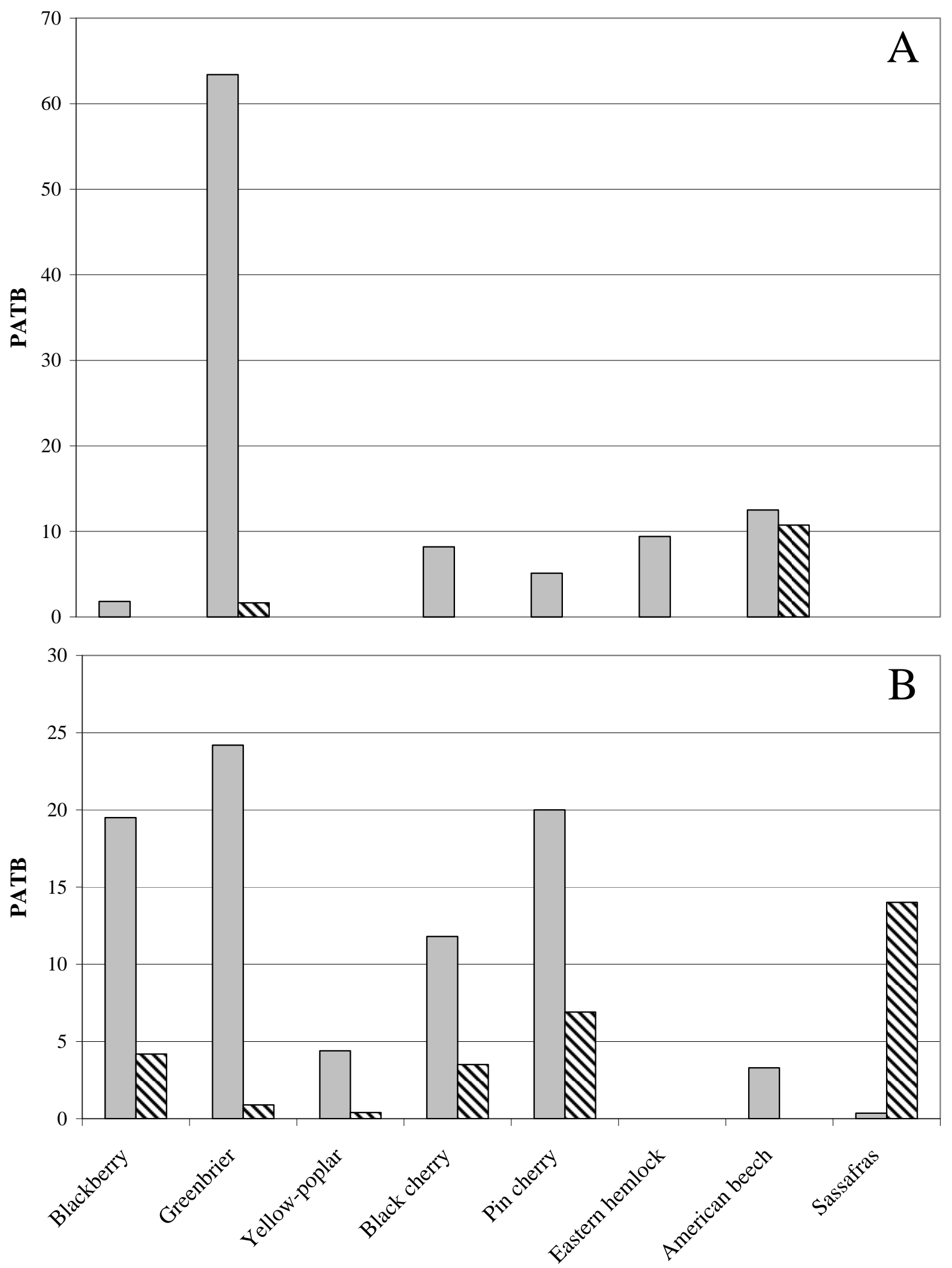

Digitally signed by John H. Hagen DN: $\mathrm{cn}=J$ ohn H. Hagen, $\mathrm{o}=$ West 